\title{
THE EFFECT OF INDUSTRIAL DIVERSIFICATION ON FIRM TAXES
}

\author{
Kelly M. Wentland
}

A dissertation submitted to the faculty of the University of North Carolina at Chapel Hill in partial fulfillment of the requirements for the degree of Doctor of Philosophy in the Kenan-Flagler School of Business.

\section{Chapel Hill}

2015

\author{
Approved by: \\ Edward L. Maydew \\ Douglas A. Shackelford \\ Eva Labro \\ Jeremy G. Moulton \\ Robert M. Bushman
}


(C) 2015

Kelly M. Wentland ALL RIGHTS RESERVED 


\section{ABSTRACT \\ Kelly M. Wentland: The Effect of Industrial Diversification on Firm Taxes (Under the direction of Edward L. Maydew)}

This study investigates whether there is an empirical basis for one predicted benefit from industrial diversification: whether a conglomerate firm incurs lower tax liabilities than pure play firms. The results indicate that, on average, firms operating in multiple industries have lower tax liabilities than stand-alone firms. In additional cross-sectional tests, I identify conditions under which firms observe (or do not observe) tax benefits from diversification. Finally, I explore two simultaneous equations techniques from the diversification literature as alternate approaches for addressing endogeneity. Overall, this study furthers our understanding of the benefits of industrial diversification, providing initial evidence that conglomerates, on average, have lower tax liabilities than single-industry firms. 
To my husband, Scott, and daughter, Holly, the most precious sight at the end of each day and forever in my heart. Thank you for all your love and support. 


\section{ACKNOWLEDGEMENTS}

I am grateful for the input and feedback of my dissertation committee: Ed Maydew (chair),

Robert Bushman, Eva Labro, Jeremy Moulton, and Doug Shackelford. In addition, I am thankful for

helpful comments and suggestions from Jeff Abarbanell, Travis Dyer, Brad Hendricks, Sangwan Kim, Martin Jacob, Mark Lang, Jim Omartian, and Vivek Raval. Finally, I thank the Accounting Doctoral

Scholars Program for financial support and AAA/Grant Thornton for selecting this dissertation for the Doctoral Dissertation Award for Innovation in Accounting Education. 


\section{TABLE OF CONTENTS}

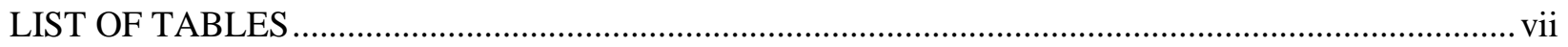

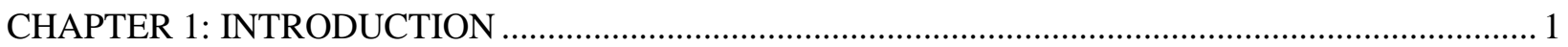

CHAPTER 2: HYPOTHESIS DEVELOPMENT AND RELATED LITERATURE ............................... 6

CHAPTER 3: RESEARCH DESIGN, SAMPLE, AND RESULTS .................................................... 11

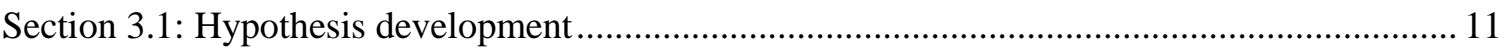

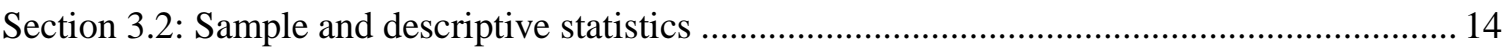

Section 3.3: OLS results using alternative measures of diversification...................................... 16

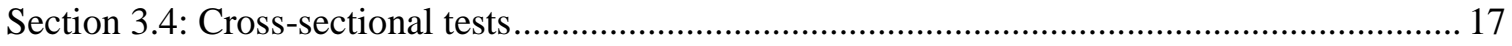

Section 3.4.1: Research design - R\&D activity ....................................................... 17

Section 3.4.2: Research design - demand for debt capacity ........................................... 18

Section 3.4.3: Research design - firm risk preferences .............................................. 20

Section 3.4.4: Results from cross-sectional tests ........................................................ 21

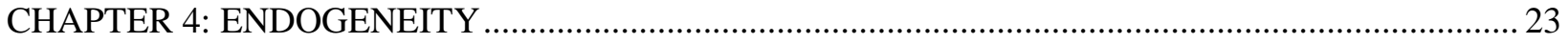

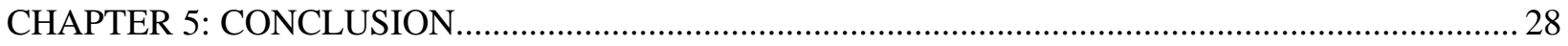

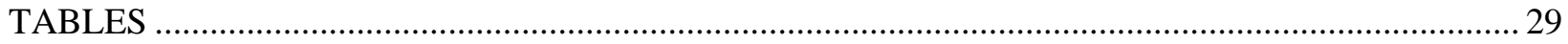

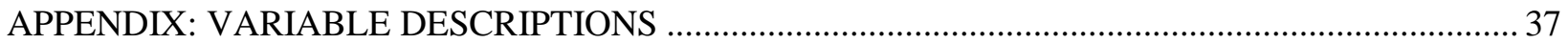

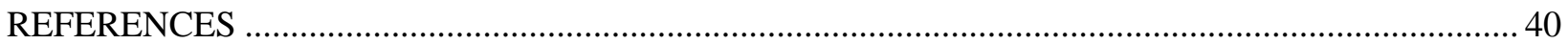




\section{LIST OF TABLES}

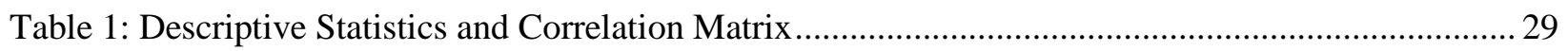

Table 2: OLS Regressions of Tax on Different Diversification Measures ............................................. 31

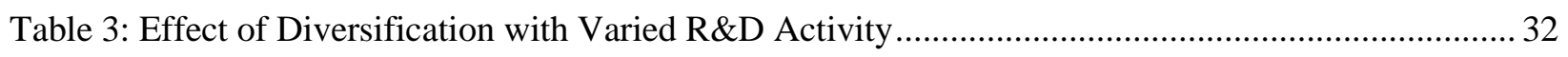

Table 4: Effect of Diversification with Varied Financial Constraints ................................................... 33

Table 5: Effect of Diversification with Varied Firm Risk ................................................................ 34

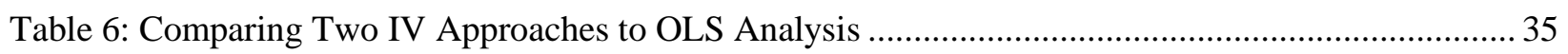




\section{CHAPTER 1: INTRODUCTION}

The media has featured a number of high-profile debates between activist investors like Trian Fund Management and management at conglomerates such as DuPont over the merits and pitfalls of operational diversification (Gopinath and Sikka, 2014). ${ }^{1}$ Given statements made by management at conglomerates like Berkshire Hathaway and General Electric, one of the key benefits from operating in multiple industries may be access to additional tax benefits. In his 2014 letter to shareholders, Warren Buffett cited "important tax benefits" as one reason voluntary spin-offs "make no sense for us" at Berkshire Hathaway (p. 33). Similarly, General Electric stated that concerns about losing tax benefits from its financing operations business unit, GE Capital, deterred the decision to sell the financing business for a long-time (Mann, 2015). In this study, I examine an empirical question central to the debate about the costs and benefits of industrial diversification: do firms operating in multiple industries pay less in taxes than firms operating in a single industry?

The appeal of the conglomerate form has waxed and waned over time with success stories like 3M Corporation and General Electric in contrast to notorious failures like Quaker Oats's entry into the fruit juice market and RCA's spread into computers, carpets, and rental cars (Markides, 1997). Some proponents of industrial diversification offer arguments for synergies in operations (e.g. leveraging research and innovation across multiple products and services), alternative financing sources (e.g. crossdivision internal capital markets as an alternative to external financing markets), and additional tax savings (Lewellen, 1971; Teece, 1980; Gertner, Scharfstein, and Stein, 1994; Furrer, 2011). Others simply

\footnotetext{
${ }^{1}$ Other examples include articles with discussions from analysts, portfolio managers, and firm management about recent spin-offs like Abbott Laboratories and Energizer (Lachapelle and March, 2015; Wieczner, 2015; Benoit and Grind, 2015).
} 
reference old adages like "not putting all your eggs in one basket" or more formal verbiage relating back to arguments for diversification in portfolio theory (Hindle, 2009). ${ }^{2}$

At the same time, opponents like investment expert Peter Lynch, who coined the term "diworsification," explain that diversifying to a certain extent may destroy the original business investment because management time, energy, and resources are diverted from the original focus (Lynch and Rothchild, 2000). Further, prior research suggests that management may be incentivized to diversify for their own benefit, rather than the interests of shareholders. ${ }^{3}$ Empirically, the financial economics literature is more consistent with the latter arguments, concluding that diversified firms trade at a discount or perform worse relative to pure play firms (specifically, see earlier studies like Lang and Stulz (1994) and Berger and Ofek (1995); more recently, Laeven and Levine (2007) in banks, and Humphery-Jenner (2013) in private equity funds). Despite this puzzle of the "diversification discount" in the valuation literature, little attention has been given to testing whether the individual benefits of diversification predicted in prior literature and practice are actually realized. That is, the diversification discount is only a puzzle as long as the assumptions about the benefits of diversification are, in fact, valid; hence, the purpose of this study is to examine the commonly held assumption that industrial diversification creates a tax benefit for firms.

To investigate the effect of diversification on firm tax liabilities, I employ an empirical model following Hope, Ma, and Thomas (2013), which includes an extensive set of predictors used to explain firm tax liabilities from prior literature. In these tests using OLS, I find evidence supporting the prediction in prior literature that firms operating in multiple industries have lower tax liabilities than single industry firms on average. This finding is robust to four measures of diversification.

\footnotetext{
${ }^{2}$ Throughout the study, I use the terms diversified firm, conglomerate, and multiple industry firm interchangeably consistent with prior literature.

${ }^{3}$ Because manager wealth comes from a single firm whereas shareholders can hold portfolios to offset risk from the individual firm, managers may prefer greater risk reduction through diversified internal operations than shareholders (Amihud and Lev, 1981). Managers may also prefer to grow the firm in a more diverse or specialized way that makes them indispensable to the firm (Montgomery, 1994).
} 
In the next set of tests, I use prior literature and institutional tax information to motivate three settings where I expect tax benefits from diversification to be more or less likely. I use these tests to identify conditions under which firms either do or do not observe tax benefits from diversification. Specifically, when the tax benefits from diversification act as a potential substitute for other tax benefits the firm may claim rather than as an incremental source of tax savings, I do not find evidence that multiple industry firms obtain significant tax savings over single industry firms. Further, I find that firms with little to only moderate demand for additional debt or following a low to moderate risk strategy do not appear to access additional tax benefits from diversification. That is, only firms with a high demand for debt capacity or high risk preference observe additional tax benefits related to diversification.

Specifically, I proxy for the potential substitution effect for tax benefits from diversification with the extent of research and development activity a firm has using the restrictions on the General Business Credit to motivate a substitution effect. I proxy for a firm's demand for additional debt capacity (risk preference) based on its financial constraints (return volatility) in the year it enters the sample. Taken together, this set of cross-sectional tests provide evidence that the main effect is properly identified in the sense that the results conform to the specific predicted sources of diversification tax benefits in the literature. Alternatively, had the tests revealed that the diversification tax benefit persists for subsets of firms where the tax benefits are not expected, it would cast doubt on whether the main effect is properly identified.

In the last set of tests, I re-examine the average effect of diversification on firm tax liabilities using instruments for diversification proposed in Campa and Kedia (2002) in analysis using both two stage least squares and treatment effects models. Using these alternate approaches, which are common to the diversification literature, I find results consistent with my primary results, supporting a tax benefit on average from operating in multiple industries.

This study contributes to the debate in the diversification literature and practice over the merits of operational diversification as a firm business strategy. Prior literature predicts there are many potential benefits from diversification (Lewellen, 1971; Teece, 1980; Gertner, Scharfstein, and Stein, 1994; Furrer, 
2011), but generally provides evidence supporting a valuation discount or underperformance for diversified firms overall when compared to single industry firms (Lang and Stulz 1994; Berger and Ofek, 1995; Comment and Jarrell, 1995; Lins and Servaes, 1999; Rajan, Servaes, Zingales, 2000; Scharfstein and Stein, 2000; Laeven and Levine, 2007; Humphery-Jenner, 2013). By documenting the specific tax savings linked with diversification, this study is the first to offer empirical support to one dimension used in assessing the merits of diversification. Further, by identifying different circumstances where I do or do not observe the tax benefit, I provide a tangible set of conditions for why we may observe differences in valuation effects across diversified firms. While assessing the valuation effect for the average firm is clearly important, examining individual benefits and costs of diversification (such as a firm's tax benefit) may provide a greater set of tools for evaluating why diversification has appeared to work for some firms (e.g. 3M and General Electric) but not others.

In addition to contributions to the diversification literature, the results in this study suggest that industrial diversification is an important factor to consider in future research on firm tax avoidance. While recent research suggests that industry expertise may be advantageous for claiming additional tax benefits (McGuire, Omer, and Wang, 2012), and previous research demonstrates that the influence of other important factors (like firm size) on taxes varies across industries (Zimmerman, 1983), studies in the literature generally link a firm with its primary industry and do not account for whether it has operations in other industries. To summarize the implications of this with an analogy, accounting for only the primary industry in which a firm operates, but not accounting for whether it operates in multiple industries, would be akin to addressing the fact that a firm is headquartered in the U.S. versus Ireland, but not accounting for the fact that it operates in multiple countries as opposed to operating only domestically. ${ }^{4}$ Moreover, unlike more complicated measures or variables that explain tax avoidance specific to proprietary data of limited accessibility, segment-based industry data is readily available in

\footnotetext{
${ }^{4}$ The two characteristics are also applicable to a similar proportion of firms. For example, from 1999-2013 (in my sample period), 25 percent of the firms on Compustat reported operating in multiple industries (based on reporting business segments in more than one four-digit SIC code), and 22 percent of firms on Compustat reported having foreign operations (based on reporting non-zero and non-missing pre-tax foreign income).
} 
Compustat and can be easily incorporated into future tax research as an important determinant of a firm's tax rate..$^{5}$

The remainder of this dissertation is organized as follows. Chapter 2 develops the hypothesis tested in the study and describes related literature. Chapter 3 details the research design, sample, and results for the primary analysis and cross-sectional tests. Chapter 4 re-examines the primary analysis using two instrumental variables techniques. Chapter 5 concludes the study discussing overall inferences and limitations.

\footnotetext{
${ }^{5}$ This is in contrast to other factors shown to have important implications for firm tax outcomes that are difficult to incorporate into an empirical examination because these characteristics are not publicly disclosed. For example, Robinson, Sikes, and Weaver (2010) use proprietary survey data to examine whether performance measurement of corporate tax departments (as a profit center as opposed to a cost center) affects firm effective tax rates. They find that firms evaluating tax departments as profit centers have significantly lower effective tax rates than firms evaluating their tax department as cost centers. Firms generally do not publicly disclose how they evaluate their tax department.
} 


\section{CHAPTER 2: HYPOTHESIS DEVELOPMENT AND RELATED LITERATURE}

Diversifying through industry operations has been linked to several sources of tax benefits in prior literature and practice. The first two predicted tax benefits from diversification come from the literature linking hedging to income volatility. Smith and Stulz (1985) define hedging as both the use of operational decisions (such as operating in multiple industries) and derivatives (or other financial instruments) to reduce the covariance of streams of income with the state of the economy. Smith and Stulz (1985) use a simple model of after-tax firm value to argue that if a firm's tax liability is a convex function of pre-tax income (i.e. the marginal tax rate is increasing with taxable income), then by Jensen's Inequality, companies that can reduce the volatility of their income through hedging can obtain lower expected tax liabilities. Graham and Smith (1999) extend this analysis using simulation models to incorporate more realistic features of the tax code, like tax loss carrybacks and carryforwards, investment tax credits, and the Alternative Minimum Tax (AMT) and find that these features do not eliminate this benefit related to tax convexity but rather extend the range of pre-tax income over which the convexity applies. ${ }^{6}$ Based on the simulation analysis, Graham and Smith (1999) conclude that the average firm in their analysis faces a convex tax function and that if firms can reduce their pre-tax income volatility by 5 percent then on average they can reduce expected tax liabilities by about 5.4 percent.

The second tax benefit predicted from this literature results from implications of hedging for optimal capital structure. Firms that hedge are expected to carry a lower risk of default and as a result lending limits by creditors should be higher (Lewellen, 1971, Leland, 1998). Thus, firms have the opportunity to trade-off risk that was not tax-favored (with more exposure to tax convexity through

\footnotetext{
${ }^{6}$ They find that primary institutional features affecting firm tax convexity are its tax loss carrybacks and carryforwards. Practically speaking, tax loss carrybacks and carryforwards do not eliminate tax convexity primarily because of the uncertainty of available taxable income to offset within the carryback and carryforward periods and the time value of money (Majd and Myers, 1987).
} 
volatile income streams in the absence of hedging) with tax-favored risk from additional debt capacity, resulting in greater interest deductions and lower tax liabilities (Lewellen, 1971; Stulz, 1996; Leland, 1998). While these first two tax benefits may come from any form of income volatility reduction or hedging, the third and fourth predicted tax benefits from diversification are unique to operational forms of hedging (in this case, operating in multiple industries) as opposed to hedging with derivatives.

These two operations-specific benefits relate to the firm's ability to both use and uphold tax positions. The tax code contains extensive provisions for tax benefits targeted at specific industries. ${ }^{7}$ The dimension of industry for tax planning is also stressed by practice. For example, all of the Big Four discuss advantages for industry specific knowledge for tax functions on their websites. ${ }^{8}$ Yet, firms often face uncertainty about whether industry-specific tax benefits will remain available, which can affect the extent to which they will use certain tax positions. ${ }^{9}$ Related to this, the third tax benefit of industrial diversification is that, by operating in different industries, a diversified firm may have a broader portfolio of tax planning opportunities and may not be as sensitive to unfavorable changes to a single industry's specific tax policies.

Another type of uncertainty that may limit a firm's use of tax positions is its expectation that whether, once a position is taken, it will be overturned by taxing authorities. The fourth benefit of operating in multiple industries is that it may reduce both the likelihood of being audited and the probability that, even if the firm is audited, the position will be overturned. This may result for two

\footnotetext{
${ }^{7}$ One example is the Investment Credit, which consists of credits specific to coal, gasification, and energy projects and the Credit for Increasing Research Activities ("R\&D tax credit") often linked to pharmaceutical, high tech, and manufacturing industries. Other examples include specialized tax treatment for intangible drilling costs for oil and gas companies and elections allowing the averaging/shifting of farm income over multiple tax years in agriculture.

${ }^{8}$ Deloitte: http://www2.deloitte.com/us/en/pages/tax/solutions/tax-services-by-industry.html; Ernst \& Young: http://www.ey.com/US/en/Industries; KPMG: http://www.kpmg.com/us/en/services/tax/pages/default.aspx; http://www.kpmg.com/us/en/industry/pages/default.aspx; PricewaterhouseCoopers: http://www.pwc.com/us/en/ industrial-products/publications/2015-tax-rate-benchmarking-study.jhtml

${ }^{9}$ For example, a last-minute bill in 2014 extended 54 corporate tax breaks (including specific tax breaks for banks, the retail industry, and research and development) that corporations would have lost access to for their returns that year (Huffington Post, December 16, 2014).
} 
reasons. First, firm taxes are often assessed by comparison with industry peers. ${ }^{10}{ }^{11}$ In fact, the Internal Revenue Service (IRS) has 52 Audit Technique Guides, which are primarily used to assist its examiners assess unique tax and accounting methods of specific industries. ${ }^{12}$ When a firm operates in different industries, it may be more difficult for a taxing authority to identify, for example, an appropriate benchmark firm to flag whether the firm as having an abnormally low tax liability or questionable estimates of tax benefits. ${ }^{13}$ Further, when a diversified firm does come under audit, it may be more difficult for IRS examiners to evaluate the appropriate tax treatment of a more complex organizational structure (e.g. understanding unique inter-industry transfer pricing techniques available to multiple industry firms). Thus, by reducing uncertainty about both available opportunities to reduce tax liabilities and the likelihood positions taken will be overturned, diversified firms may be able to pay less in taxes than stand-alone firms. More broadly, the fact that the IRS audits based on industry-specific guidelines should alert tax researchers to the potential importance of investigating factors related to industries, and helps motivate the current study from a practice standpoint.

Despite the potential for additional tax savings, there are at least four reasons diversified firms may not obtain lower tax liabilities than pure play firms (i.e. they may even have higher tax liabilities). First, the last benefit mentioned cuts both ways, in the sense that while it may be more difficult for auditors to audit a multi-industry firm (given industry-specific tax code provisions), it may also be more difficult or costly for firms to tax plan for multiple industries. Alternatively, pure play firms operating in a single industry may have a tax department that is highly specialized, in a better position to know their

\footnotetext{
${ }^{10}$ In a 2014 report on tax planning benchmarks, Pricewaterhouse Coopers explained that peer group comparisons, which are often based on industry, provide opportunities in planning and shaping the tax function: http://www.pwc.com/us/en/industrial-products/publications/2015-tax-rate-benchmarking-study.jhtml.

${ }^{11}$ The IRS offers Industry Specific Tax Centers to provide businesses with specific guidance and analysis tools for assessing their tax planning relative to their industry.

${ }^{12}$ IRS Audit Technique Guides are available at: http://www.irs.gov/Businesses/Small-Businesses-\&-SelfEmployed/Audit-Techniques-Guides-ATGs.

${ }^{13}$ For example, it may difficult to identify an appropriate "tax peer" for companies that are diversified like 3M or General Electric.
} 
industry's tax provisions inside and out, so-to-speak. Dating back as early as Adam Smith, the gains from specialization have been well-established in economics, and there is no reason to believe that gains from specialization should not apply to tax practitioners at large, publically traded companies. An intuitive explanation of the tax cost for operating in multiple industries is simply that these firms' tax departments are simply spread too thin, or less specialized, and therefore less adept at maintaining tax rates as low as single-industry firms. ${ }^{14}$

Second, risk reduction is documented as an important motivator for diversification (Amihud and Lev, 1981). Shareholders can achieve their own desired level of risk through portfolio diversification and, thus, may have higher preference for the risk (and related returns) from any single firm. Instead, managers often maintain a major portion of their total income from their employment with a single firm through profit-sharing schemes, bonuses, and the value of stock options. As a result, a risk-averse manager may opt for the conglomerate form as a means to stabilize the firm's streams of income, even if it is not valued by shareholders. ${ }^{15}$ As a result of this, diversified firms may simply not take advantage of additional tax planning opportunities even if they do exist (i.e. demonstrate no significant difference with stand-alone firms in terms of tax savings) or may even choose to reduce tax benefits taken if diversification is part of an overall firm strategy to reduce risk (paying higher taxes than pure play firms).

Third, prior literature on derivatives and mergers and acquisitions (M\&A) suggests firms may not receive all of the specific, predicted tax benefits from hedging. Graham and Rogers (2002) and Donohoe (2015) test the predictions from Graham and Smith (1999) that there may be tax incentives to hedge through derivatives. While Graham and Rogers (2002) find evidence consistent with greater interest tax shields from derivative use and Donohoe (2015) finds evidence of additional tax benefits unique to

\footnotetext{
${ }^{14}$ This viewpoint is consistent with the concerns about diverting management resources from the original focus of operations expressed in Lynch and Rothchild (2000).

${ }^{15}$ Based this explanation, Amihud and Lev (1981) predict and find that the number of conglomerate mergers increases as the type of control in the firm moves from strong shareholder control to weak shareholder control and then to management control. At the same time, this type of control does not appear to be a significant motivator for non-conglomerate mergers, suggesting that the effect is not for general growth with mergers as opposed to the conglomerate form distinction. Further, May (1995) finds that firms with CEOs that have more personal wealth vested in their firm's equity tend to diversify firm operations.
} 
transactions with derivatives, neither study finds evidence that supports derivative use providing additional tax benefits from reduced tax convexity. Further, in their multivariate analysis, Devos, Kadapakkam, and Krishnamurthy (2009) do not find evidence of greater debt tax shields from diversifying M\&A in comparison to focused M\&A. Overall, the results in these studies cast doubt on some of the individual tax benefit predictions from the general hedging and diversification specific literatures, motivating a more general empirical examination of industrial diversification on firm tax liabilities.

Finally, as mentioned in the introduction, while diversification is predicted to provide a number of other non-tax benefits that are expected to generate greater firm value (in addition to the tax benefits above), and a significant portion of firms continue to choose to operate in multiple industries, generally the literature finds evidence that, on average, diversified firms are valued at a discount or perform worse relative to pure play firms. This suggests that either firms are not realizing these benefits in reality or that, even if these benefits are being accessed, additional costs of the conglomerate form (which may have alternative tax consequences) offset these benefits for shareholders. While the above alternative points suggest it may be reasonable to expect that diversified firms claim no greater tax advantages than standalone firms, I state the following hypothesis based on the greater tax benefit prediction (in the alternative form) given this is the perspective focused on in the diversification literature:

H1: Diversified firms obtain lower tax liabilities on average. 


\section{CHAPTER 3: RESEARCH DESIGN, SAMPLE, AND RESULTS}

\subsection{Research design for hypothesis 1}

To examine the hypothesis of this dissertation, H1, I employ an empirical model similar to Hope, Ma, and Thomas (2013):

$$
\text { Taxi }_{i, t}=\beta_{0}+\beta_{1} \text { Diversification }_{i, t}+\sum \beta \text { Controls }_{i, t}+\varepsilon_{i, t}
$$

To measure a firm's tax liabilities, $\operatorname{Tax}_{i, t}$, I use a firm's cash taxes paid scaled by the market value of assets (Cash taxes paid/MVA $A_{i, t}$ ). Henry and Sansing (2015) document evidence that scaling by this market value of assets helps address concerns about data truncation bias. Scaling by this variable is particularly important for examining taxes in the setting of diversification for two reasons. First, because ETR-based measures divide by pre-tax book income reported in the financial statements, it only allows the measure to capture non-conforming (as opposed to conforming) forms of tax avoidance (Hanlon and Heitzman, 2010). Conforming (non-conforming) tax avoidance is a reduction in firm tax liability that affects a firm's taxable income and pre-tax book income in the same way (differing ways). Because ETRbased measures do not capture conforming tax avoidance, it will not reflect tax benefits of interest deductibility (Hanlon and Heitzman, 2010, p. 141) and potentially bias the results in a way directly relevant to this study's hypothesis.

In addition, ETR-based measures are generally not considered meaningful in years with negative pre-tax income (Dyreng, Hanlon, and Maydew, 2008; Hope, Ma, and Thomas, 2013). ${ }^{16}$ As a consequence of this, studies using ETR measures generally exclude years with negative pre-tax income from the analysis. This restriction is of particular concern in this study because one of the predictions from the

\footnotetext{
${ }^{16}$ For example, say a firm has negative pre-tax income and had negative cash taxes paid (i.e. a refund when it has a loss). The ETR would be positive and potentially larger than for some firms that actually had positive pre-tax income and cash taxes paid. Alternatively, a firm could have negative pre-tax income and positive taxes paid, resulting in a negative ETR when taxes were actually paid.
} 
literature is that diversification is expected to reduce income volatility, which may indicate that generally profitable diversified firms face less frequent exposure to loss years than stand-alone firms. As a result, this truncation restriction for negative pre-tax income years may affect diversified firms to a different extent than stand-alone firms and introduce a systematic bias in the estimator.

The variable Cash taxes paid/MVA $A_{i, t}$ is able to capture conforming tax avoidance and allows the inclusion of negative pre-tax income years because of the alternative scaling variable, market value of assets. As explained in Hanlon and Heitzman (2010), a tax measure is able to capture conforming tax avoidance if the conforming tax avoidance does not affect the numerator and denominator of the tax measure in a way that preserves the value of the ratio without this type of avoidance (they discuss this in the context of scaling by cash flows from operations as an alternative to pre-tax book income in footnote 49). ${ }^{17}$ It is reasonable to expect that lower cash taxes paid as a consequence of interest tax deductions would not affect the market value of assets in such a way that it would maintain the same ratio in the absence of such tax benefits. Thus, I expect this form of tax avoidance to be captured in this alternate measure. Further, the use of market value of assets as the scaling term precludes elimination of negative pre-tax income years because it maintains a meaningful ratio in these years (because the denominator is still positive in these years). ${ }^{18}$

The primary variable for Diversification ${ }_{i, t}$ is an indicator for whether a firm operates in multiple industries (Multiple industries ${ }_{i, t}$ ) similar to Berger and Ofek (1995) and prior literature on diversification, taking the value of one when a firm operates in multiple industries and equaling zero otherwise. In

\footnotetext{
${ }^{17}$ Hanlon and Heitzman (2010) discuss cash flow from operations as an alternative scaler to use to try and capture conforming tax avoidance. However, cash flow does not as clearly eliminate the two concerns above for two reasons. First, it is more reasonable to expect that interest expense and the related tax deduction would affect the cash flow denominator and cash taxes paid in a way that preserves the tax variable ratio in the absence of this expense/deduction than it is to expect that this ratio would be maintained in the presence of this tax benefit when scaling by market value of assets. Further, scaling by cash flow from operations does not resolve the issue of truncation with negative denominator values as cash flow is negative nearly as frequently as when pre-tax income is negative. However, I do want to note that Hanlon and Heitzman (2010) do not offer the alternative cash flow scaling variable as a suggestion for addressing the loss truncation issue.

${ }^{18}$ See Henry and Sansing (2015) for a discussion of the motivation and validation of the alternate scaling variable in addressing truncation bias in tax measures.
} 
addition to Multiple industries $s_{i, t}$, I examine three alternative proxies for Diversification ${ }_{i, t}$ based on firm segment reporting: \# of industries ${ }_{i, t}, \%$ sales in other industries $s_{i, t}$, and Sales-weighted distance ${ }_{i, t}$. The variables Multiple industries,$t$, and \# of industries $_{i, t}$ follow from the single versus multi-segment firm representation of diversification used in Berger and Ofek (1995). The measure \% sales in other industries $_{i, t}$ is based on the measure of multinational or geographical diversification in Creal, Robinson, Rogers, and Zechman (2013), which uses the percent of foreign sales as the extent of diversification. Sales-weighted distance $_{i, t}$ captures how similar the segmented industries inside the firm are to the primary industry of the overall firm. This measure is based on the "relatedness" measure used in Khorana, Shivdasani, Stendevad, and Sanzhar (2011). I use a decile rank form of the latter two measures, \% sales in other industries $_{i, t}$ and Sales-weighted distance ${ }_{i, t}$ for ease of comparison across the two measures. Based on $\mathrm{H} 1$ and the standard assumption in the diversification literature, I expect to find that more diverse firms pay less in taxes on average (i.e. a negative and significant coefficient estimate on Diversification ${ }_{i, t}\left(\beta_{1}\right)$ ).

Following prior literature on tax avoidance, I include an extensive set of control variables to account for other tax planning opportunities, incentives, and common firm activities with differences in book (financial accounting) and tax reporting that may affect firm taxes. The extent of foreign operations (Foreign pre-tax income ${ }_{i, t}$ ) and a firm's decision to not disclose disaggregated geographic earnings (No disclosure $_{i, t}$ ) are associated with lower firm taxes (Rego, 2003; Hope, Ma, and Thomas, 2013). Larger firms may have greater economies of scale for tax planning yet may draw greater attention from tax authorities and the public, generating mixed predictions for the effect of firm size $\left(\right.$ Size $\left._{i, t}\right)$ on firm taxes (Zimmerman, 1983; Gupta and Newberry, 1997; Rego, 2003). Firms with additional leverage (Leverage $_{i, t}$ ) may benefit from additional debt tax shields. Available tax loss carryforwards (Tax Loss Carryforward $_{i, t}$ ) and whether the firm has gathered (used) more of these carryforwards in the current period (Increase in tax loss carryforward ${ }_{i, t}$ ) can also affect firm taxes. Inclusion of controls for tax loss carryforwards are particularly important in this setting because they may offset some of the consequences of asymmetric tax treatment of income and losses. 
More profitable firms (proxied by Pre-tax income $e_{i, t}$ ) may have higher taxes simply because of related higher taxable income. Yet, at the same time, these firms may have greater incentives and resources to lower their taxes (Rego, 2003; Henry and Sansing, 2015). The remaining controls represent firm activities that are treated differently for book and tax reporting purposes, which may also affect firm taxes. Specifically, I inlcude controls for fixed assets $\left(P P \& E_{i, t}\right), \mathrm{R} \& \mathrm{D}$ and intangibles intensity $\left(R \& D_{i, t}\right.$ and Intangibles $\left._{i, t}\right)$, and the extent of earnings from unconsolidated subsidiaries (Equity Income $e_{i, t}$ ). Finally, following the prior literature on diversification, I include firm (i) and year (t) fixed effects to account for other, unobserved, time-invariant factors across firms (e.g. general firm business strategy) and other factors that may vary for all firms across time (e.g. macroeconomic conditions or tax policy changes). ${ }^{19} 20$

\subsection{Sample and descriptive statistics}

The Compustat sample used for this study runs from 1999 to 2013. Statement of Financial Accounting Standards No. 131 (SFAS 131) changed the requirements for segment reporting for all fiscal years beginning after December 15, 1997. Because the diversification measures come from business segment data, I begin the sample in 1999 to have consistent segment reporting requirements throughout the entire sample period. I exclude firm-years with more than one observation for a firm (e.g. a year when a firm changes its fiscal year-end). I then require non-missing values for Cash taxes paid/MVA ${ }_{i, t}$, Multiple Industries $_{i t}$, and the control variables discussed in equation (1) as described in Appendix I. Similar to prior literature examining diversification using segment data, and to ensure completeness of firm segment

\footnotetext{
${ }^{19}$ Discussions in prior literature suggest that unobserved, time-invariant factors affecting a firm's diversification choice can influence the observed outcomes of diversification. A common approach to account for these factors in the diversification literature is the inclusion of firm and year fixed effects in an OLS specification (Campa and Kedia, 2002; Dimitrov and Tice, 2006; Lin, Pantzalis, and Park, 2007; Gopalan and Xie, 2011; Ammann, Hoechle, and Schmid, 2012; and Hoechle, Schmid, Walter, and Yermack, 2012). Laeven and Levine (2007), Klein and Saidenberg (2010), and Goetz, Laeven, and Levine (2013) focus on forms of diversification in financial institutions and incorporate bank level fixed effects in their designs for the same purpose. I have also considered industry and year fixed effects. However, this approach fails to account for factors that vary across firms within each industry, which may bias inferences made with this analysis. Results with industry and year fixed effects differ.

${ }^{20}$ All of the studies applying the firm fixed effects model discussed in the prior footnote (except Goetz, Laeven, and Levine (2013)) use instrumental variable techniques with instruments proposed in Campa and Kedia (2002) in conjunction with their OLS fixed effects models to address endogeneity concerns. I perform analysis using these instruments in Chapter 4.
} 
reporting for the diversification measures, I exclude firm-years where the sum of sales or assets across reported segments deviated from the firm's total sales or assets, respectively, by more than ten percent. ${ }^{21}$ The final sample has 26,910 firm-year observations. ${ }^{22}$

Panel A of Table 1 reports the descriptive statistics for the sample. The number of observations differs for alternate continuous measures of diversification, Return Volatility ${ }_{i, t}$, and SA Index I $_{i, t}$ because these continuous measures are not required for the primary sample, but are confined to the specific analysis using these additional variables. The average Cash taxes paid/MVA $A_{i, t}$ of 0.0091 is analogous to an average cash ETR of 0.32, which is consistent with the mean cash ETR values in Hope, Ma, and Thomas (2013). ${ }^{23}$ Overall, the control variable summary statistics are similar to those in Hope, Ma, and Thomas (2013) and prior literature.

Table 1 Panel B reports the descriptive statistics for the multiple industry and single industry subsamples. Overall, firm-years with operations in multiple industries make up 20 percent of the full sample. A few other descriptive statistics from this table are worth noting. Related to specific predictions for taxes, on average, firms operating in multiple industries have higher Cash taxes paid/MVA $A_{i, t}$ values but lower Leverage $_{i, t}$. The higher Cash taxes paid/MVA $A_{i, t}$ and lower Leverage $e_{i, t}$ means for multiple industry firms provide preliminary evidence in contrast to the literature's predictions for tax benefits overall and

\footnotetext{
${ }^{21}$ For example, Berger and Ofek (1995) and Campa and Kedia (2002) require non-missing segment data and exclude observations where the sum of segment values of sales deviates from the Compustat annual total sales value by one percent. In more recent studies, Ammann, Hoechle, and Schmid (2012) and Hoechle, Schmid, Walter, and Yermack (2012) exclude observations where the sum of segment values of sales or assets deviates by five percent. I use a ten percent threshold for this comparison to maintain as many observations as I can while still ensuring completeness. The ten percent threshold for sales and assets is based on the SFAS 131 threshold defining a reportable segment.

${ }^{22} \mathrm{~A}$ comparison of the descriptive statistics for my final sample and Compustat using one-sample z-statistics shows that for most variables there is no statistical difference in means. However, of those variables with a statistical difference, the only ones with much difference in terms of economic magnitudes (a difference of greater than 5 percent) are Increase in tax loss carryforward ${ }_{i, t}$ and Pre-tax income $i, t$. However, there is no difference in the median Increase in tax loss carryforward ${ }_{i, t}$ across my sample and Compustat, and the medians are much closer in value for Pre-tax income $e_{i, t}$ ( 2 percent of total assets for Compustat and 4 percent of total assets for my sample). This suggests the differences in means for these variables results from the presence of more extreme values for these variables in Compustat that affect the mean but not the median values. Thus, the two differences observed do not offer an obvious indication of bias for my analysis.

${ }^{23}$ The cash ETR value is calculated by multiplying Cash taxes paid/MVA $A_{i, t}$ with the average MVA for the sample $(2,526)$ and dividing by the average pre-tax income for the sample $(71)$.
} 
for additional interest tax shields from diversification. Consistent with the comparison of means, in Panel $\mathrm{C}$, the Pearson (Spearman) correlations reported above (below) the diagonal in Panel C show a positive relation between Cash taxes paid/MVA $A_{i, t}$ and each of the diversification measures, suggesting Diversification $_{i, t}$ relates to paying higher taxes. At first glance, this suggests that diversified firms may not have access to greater tax savings and may even have higher tax liabilities. However, this observation is based on univariate analysis and does not account for both observable and unobservable differences between firms, which are considered in the later multivariate tests. A final point on the correlation matrix is that the four proxies for diversification are significantly and positively correlated as expected if these variables capture the same construct.

\subsection{OLS results using alternative measures of diversification}

The results for the OLS estimations of equation (1) are reported in Table 2. The different columns in Table 2 use the aforementioned four alternative proxies for Diversification $n_{i, t}$. Generally, the control variables have the predicted associations with taxes from prior literature. For example, I observe that firms with greater values of Leverage $_{i, t}$ and $R \& D_{i, t}$ have lower values of $\operatorname{Tax}_{i, t}$. The R-squared values in my analysis are also reasonable in comparison with recent tax avoidance studies using similar models.

With respect to $\mathrm{H} 1$, the prediction that diversified firms have lower tax liabilities than stand-alone firms on average suggests that I should observe a negative relation between Diversification $_{i, t}$ and Cash taxes paid/MVA ${ }_{i, t}$. Consistent with this, the coefficient on Diversification ${ }_{i, t}$ across all four columns is negative and significant (t-statistics ranging from -1.92 to -2.35 ), indicating that diversification is associated with paying lower tax liabilities. ${ }^{24}$ For ease of interpretation, I focus on column (1) for discussion of economic magnitudes as this uses the primary measure of Diversification $_{i, t}$ in the literature. Based on column (1), I find that, on average, firms operating in multiple industries have a 0.0013 lower Cash taxes paid/MVA $A_{i, t}$ than firms operating in a single industry. ${ }^{25}$ At the sample average, this is

\footnotetext{
${ }^{24}$ Results are robust to instead running a simplified firm and year fixed effects model excluding controls.

${ }^{25}$ Results throughout the study are robust to controlling for MVA.
} 
analogous to a 4.6 percentage point lower cash ETR associated with Diversification ${ }_{i, t}{ }^{26}$ In terms of comparable magnitudes, Gallemore and Labro (2015) find that an absence of a restatement due to errors (absence of a Section 404 material weakness) is associated with a 2 (5) percentage point reduction in cash ETR.

The results from Table 2 support the anecdotes from management at conglomerates like Berkshire Hathaway and General Electric suggesting that tax benefits for diversification may offer one explanation for why these firms do not (or at least hesitate to) spin-off different operating components to refocus. Further, this offers empirical support for what has previously been an assumed benefit in the diversification literature. However, given the attention by activist investors and the evidence for the diversification discount in prior literature, it is possible that not all firms that diversify realize these tax benefits.

\subsection{Cross-sectional tests}

In this section, I investigate settings that could be effective null or zero tests, identifying subsets of firms where I may not expect to observe significant tax savings from diversification, while contrasting them with subsets of firms where I would expect to find the most pronounced effect. Predictable crosssectional variation in the diversification effect could provide initial evidence that the primary effect is properly identified (or at least not spuriously related to taxes). Further, these cross-sectional tests provide a more nuanced view of the main effect, which could help inform the broader valuation literature on the costs and benefits of industrial diversification.

\subsubsection{Research design $-R \& D$ activity}

One way that diversification may not offer additional tax benefits to firms would be if the additional potential tax benefits it produces directly reduces access to other forms of tax benefits the firm would have as a single industry firm. For example, the General Business Credit (GBC) allowed by the

\footnotetext{
${ }^{26}$ The cash ETR interpretation for the average sample firm is calculated by multiplying the Cash taxes paid/MVA $A_{i, t}$ coefficient with the average MVA for the sample $(2,526)$ and dividing by the average pre-tax income for the sample (71).
} 
IRS is an aggregation of the R\&D tax credit and 35 other tax incentives, such as the investment credit, enhanced oil recovery credit, renewable electricity production credit, and incentives for agricultural business. ${ }^{27}$ However, the aggregate GBC amount is limited based on the excess of the taxpayer's net tax liabilities over $\$ 25,000$. Thus, a firm that already has access to one type of credit (e.g. a large $R \& D$ tax credit) under the GBC may not gain as much from accessing other GBC incentives for other industries. Based on this example, the first test investigates whether firms with greater levels of research and development $(\mathrm{R} \& \mathrm{D})$ activity observe less tax benefits from diversification.

I proxy for the potential tax benefit substitution effect with the extent of R\&D activity a firm has $\left(R \& D_{i, t}\right)$, re-estimating equation (1) for partitions of low, moderate, and high R\&D activity. Specifically, I classify a firm as $L o w R \& D(H i g h R \& D)$ if it has $R \& D_{i, t}$ less than the $33^{\text {rd }}$ percentile (greater than the $67^{\text {th }}$ percentile) for $R \& D$ active firms during the year. ${ }^{28}$ Firms with $R \& D_{i, t}$ between the $33^{\text {rd }}$ and $67^{\text {th }}$ percentile for $\mathrm{R} \& \mathrm{D}$ active firms during the year are classified as Moderate $R \& D$. I predict that if diversification offers distinct, industry-specific tax benefits, like those listed in the GBC, then I should observe (should not observe) tax savings related to diversification when I expect industry specific tax benefits to be incremental to (substitutable for) industry-specific tax benefits the firm would have access to as a single industry firm as proxied by low $R \& D$ (high $R \& D$ ). Conversely, if the tax benefit I observe on average is unrelated to industry-specific tax benefits (like those in the GBC), then I would be less likely to observe a difference in the diversification effect across the high and low R\&D partitions (as evidence of a substitution effect).

\subsubsection{Research design-demand for debt capacity}

Next, I examine whether firm demand for debt capacity affects the extent of tax benefits from diversification. One source of tax benefits from diversification is predicted to follow from increased debt capacity and the related interest deductions (Lewellen, 1971; Stulz, 1996; Leland, 1998). However, for

\footnotetext{
${ }^{27}$ For a comprehensive list of the other tax incentives, see IRC Sec. 38(b).

${ }^{28} \mathrm{R} \& \mathrm{D}$ active firms are considered those that have non-zero $R \& D_{i, t}$.
} 
diversification to generate tax benefits through this channel, a firm must actually take advantage of additional debt financing. Thus, I expect that firms with greater (less) demand for additional debt to be more likely to obtain greater (fewer) tax benefits from diversification. I use whether a firm is financially constrained to proxy for its demand for additional debt capacity.

Traditional pecking order theory suggests that firms prefer internal to external financing, and then debt to equity financing, at least in part because of the high transaction costs of issuing new securities (Myers, 1984; Fama and French, 2002). This model predicts that a firm's use of debt is driven by a firm's net cash flows or financial constraints in that more financially constrained firms are forced into using equity financing when they would otherwise prefer internal funds or leverage. Thus, I would expect that if diversification offers additional debt capacity in general that financially constrained firms would be those most likely to take advantage of it.

I proxy for firm financial constraints using the $S A$ index $_{i, t}$ from Hadlock and Pierce (2010), where higher values of the index represent greater financial constraint. ${ }^{29} \mathrm{I}$ re-estimate equation (1) for partitions of low, moderate, and high financial constraints. Specifically, I classify a firm as having Low Constraints (High Constraints) if it has an SA index value less than the $33^{\text {rd }}$ percentile (greater than the $67^{\text {th }}$ percentile) value for firms in the year it enters the sample. A firm with an SA index between the $33^{\text {rd }}$ and $67^{\text {th }}$ percentile values in the year it enters the sample is classified as having Moderate Constraints. I predict that if diversification offers firms additional debt capacity and related interest tax shields then I should (should not) observe tax savings related to diversification when firms are more highly (less) constrained. Conversely, if diversified firms do not observe gain access to additional debt capacity (and related debt tax shields), I should not expect to observe a different diversification effect across the low and high constraint partitions.

\footnotetext{
${ }^{29}$ See the detailed definition for the variable in Appendix I.
} 


\subsubsection{Research design - firm risk preferences}

Finally, recall the prediction that diversification may be part of a more general, firm strategy or preference and that this may influence observed outcomes from diversification. While in my test for the on average effect (in Table 2) I attempt to control for unobserved firm strategies by including firm fixed effects, in my last cross-sectional test I consider one dimension of general firm strategy and how that affects the tax benefits observed with diversification. ${ }^{30}$ Specifically, I consider tax outcomes related to diversification for firms with different risk preferences.

Earlier in the study, I predicted that one reason I may not observe tax benefits from diversification is because it may be part of a firm's general low risk strategy where these firms simply choose not to take advantage of additional tax savings even if they are available. If this prediction holds, then I should not observe tax benefits from diversification for low risk firms. Alternatively, if any tax savings opportunities are available from diversification, I would expect high risk firms that diversify to be those most likely to claim these benefits.

To assess whether differences in firm risk influence observed tax benefits from diversification, I use a common measure for firm risk, a firm's Return volatility $y_{i, t}$, in the year it enters the sample and reestimate equation (1) on partitions for low, moderate, and high risk strategy firms. ${ }^{31}$ Similar to the test partitioning on the SA index, I classify a firm as Low Risk (High Risk) if it has return volatility less than the $33^{\text {rd }}$ percentile (greater than the $67^{\text {th }}$ percentile) value for firms in the year it enters the sample. A firm with return volatility between the $33^{\text {rd }}$ and $67^{\text {th }}$ percentile values in the year it enters the sample is classified as Moderate Risk. I predict that if diversification offers additional tax savings in general I

\footnotetext{
${ }^{30}$ The results in Table 2 for the on average effect are robust to including the variables I use to proxy for firm risk preference and demand for debt capacity (return volatility and SA index, respectively). Equation (1) already includes the $R \& D$ variable (used for the first cross-sectional test) as a control.

${ }^{31}$ See the detailed definition for the variable in Appendix I.
} 
should be most likely (least likely) to observe evidence of this savings when firms follow a high risk (low risk) strategy. ${ }^{32}$

\subsubsection{Results for cross-sectional tests}

Results for the cross-sectional tests for firm R\&D activity, demand for debt capacity, and risk preference are reported in Tables 3-5, respectively. Columns (1)-(3) in each table report the estimation of equation (1) for firms with low, moderate, and high values of the partitioning variables, respectively.

While I do not make specific predictions related to the moderate (middle) columns, I include them for completeness. Note that in some of the columns the regression analysis drops No disclosure di,t $_{\text {because }}$ there is not enough variation in the variable within that partition (after controlling for other covariates) to include it.

The R\&D test results in Table 3 show that for firms with low R\&D activity (where I expect the greatest potential for incremental tax benefits from the GBC) Diversification ${ }_{i, t}$ has the predicted negative relation with Cash taxes paid/MVA $A_{i, t}$ (column (1): coefficient -0.0013 , $t$-statistic -2.11$) .{ }^{33}$ Further, for firms with high R\&D activity in column (3) (those more likely to have a substitution effect with the GBC), I do not find evidence of lower tax liabilities from diversification. Specifically, the coefficient ( $t$ statistic) on Diversification $_{i, t}$ in this column is 0.0056 (1.58). A cross-equation test indicates that the coefficient estimates of Diversification ${ }_{i, t}$ in columns (1) and (3) (Low R\&D and High R\&D firms, respectively) are statistically different $\left(\chi_{2}=16.50, p\right.$-value $\left.=0.000\right) .{ }^{34}$ Overall, the results in Table 3 are

\footnotetext{
${ }^{32} \mathrm{~A}$ setting I considered but did not include in the cross-sectional analysis is the role of variation in corporate governance on potential tax benefits from diversification. However, this set of cross-sectional tests is the focus of a recent working paper Zheng (2015). Like Zheng (2015), I do not find evidence of differences in the diversification effect across different proxies for corporate governance factors such as institutional ownership or insider ownership.

${ }^{33}$ I include the variable $R \& D_{i, t}$ as a control for each partition to account for variation in R\&D activity within the partition. However, if I exclude this control and re-estimate each column, the sign, magnitude, and significance of the coefficient on Diversification $_{i, t}$ is very similar and do not change the inferences made above. For example, the reestimation for column (1) has a coefficient of -0.0014 and the t-statistic is -2.17 .

${ }^{34}$ The cross-equation tests throughout this section are performed by estimating the low and high column regressions demeaning by firm and year. The tabulated OLS regressions with firm and year fixed effects use the xtreg command with the dfadj option to account for degrees of freedom from the firm fixed effects. However, the command for the cross-equation test in Stata (suest) does not support xtreg command nor the robust option. For this reason, I run the
} 
consistent with incremental, industry-specific, tax benefits contributing to the on average diversification tax benefit observed in Table 2 .

In Table 4, I use the firm's SA index value in the year it enters the sample as a measure of demand for debt capacity. I only observe greater tax savings related to Diversification $_{i, t}$ (a negative association with firm tax liabilities) in the partition for firms with high financial constraints (with the highest expected demand for debt capacity) (column (3): coefficient -0.0025 , $t$-statistic -2.21 ). For low constraint (demand) firms in column (1), I do not find evidence of significant tax savings for diversified firms. Specifically, the coefficient ( $t$-statistic) on Diversification $n_{i, t}$ in this column is $-0.0001(-0.15)$. A cross-equation test indicates that the coefficient estimates of Diversification ${ }_{i, t}$ in columns (1) and (3) (Low Constraint and High Constraint firms, respectively) are statistically different $\left(\chi_{2}=11.13, p\right.$-value $=$ 0.001). Thus, the results in Table 4 are consistent with firms gaining access to greater debt capacity and related tax shields through diversification.

In Table 5, I use the firm's return volatility in the year it enters the sample as a measure of firm risk preference. I do not observe support for additional tax savings from diversification for either low or moderate risk firms. Specifically, the coefficients ( $t$-statistics) on Diversification ${ }_{i, t}$ in this columns (1) and (2) are $0.0000(0.04)$ and $-0.0008(-0.807)$, respectively. I only find greater tax savings associated with Diversification $_{i, t}$ (a negative association with firm tax liabilities) for high risk firms (column (3): coefficient -0.0035 , t-statistic -3.09). A cross-equation test indicates that the coefficient estimates of Diversification $_{i, t}$ in columns (1) and (3) (Low Risk and High Risk firms, respectively) are statistically different $\left(\chi_{2}=8.85, p\right.$-value $\left.=0.003\right)$. The results in Table 5 suggest that firms diversifying, potentially as part of a low risk firm strategy, do not claim tax benefits from diversification. Taken together, the results from the cross-sectional tests conform to expectations about the underlying motivations for the tax benefit from diversification and support the primary results by providing settings where the effects, if properly identified, should be plausibly different.

firm and year demeaned regression with the traditional reg command analogous to firm and year fixed effects to perform the cross-equation test. 


\section{CHAPTER 4: ENDOGENEITY}

The literature on diversification has documented a number of selection and endogeneity issues and has provided some guidance toward addressing them. ${ }^{35} \mathrm{~A}$ series of studies in the literature have focused on whether the reasons firms choose to diversify explain why prior research documents a negative relation between firm value and diversification (i.e. the "diversification discount"). My primary tests include firm and year fixed effects to account for unobserved time invariant factors across firms (like general firm business strategy) and macroeconomic conditions that affect all firms in a given year in the same way, which may be endogenous to a firm's decision to diversify. Further, the cross-sectional tests provides some additional evidence that the main tax effect observed is not spurious by documenting a tax benefit (or lack of tax benefit) from diversification where it is most (least) expected. In this section, I use two alternative techniques from the literature to address additional concerns with endogeneity.

Campa and Kedia (2002) use the fixed effects approach in my primary analysis and two additional techniques using a simultaneous equation framework, a two-stage least squares (2SLS) and treatment effects model (a form of selection model), to account for the endogeneity of a firm's diversification choice. ${ }^{36}$ To this end, I consider a set of firm, industry, and year level instruments $\left(I_{i, t, k}\right)$ for diversification proposed in Campa and Kedia (2002) in the following equations where:

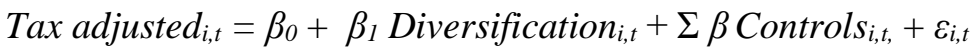

$$
\begin{aligned}
& \text { Diversification }_{i, t}=\alpha_{0}+\sum \alpha I_{i, t, k}+\sum \alpha \text { Controls }_{i, t}+\mu_{i, t}
\end{aligned}
$$

\footnotetext{
${ }^{35}$ Examples include: Campa and Kedia (2002), Graham, Lemmon, and Wolf (2002), Villalonga (2004a,b), and Li and Prabhala (2007).

${ }^{36}$ The approaches and instruments proposed in Campa and Kedia (2002) have been used frequently in the diversification literature to address endogeneity concerns, including in the following studies: Dimitrov and Tice (2006), Laeven and Levine (2007), Lin, Pantzalis, and Park (2007), Klein and Saidenberg (2010), Gopalan and Xie (2011), Ammann, Hoechle, and Schmid (2012), Hoechle, Schmid, Walter, and Yermack (2012), and Hann, Ogneva, and Ozbas (2013).
} 
Following their study, I use two firm instruments to account for the ease with which a firm can change between being diversified and focused in a single industry. Specifically, firms included in the $S \& P$ Index $x_{i, t}$ and Listed on a Major Stock Index $x_{i, t}$ are expected to have greater visibility and liquidity, making it easier to move between a diversified and focused structure. The time instruments are proxies for business cycles, macroeconomic conditions, and merger waves. Business cycles and macroeconomic conditions are captured by the concurrent and lagged \# of Contraction Months during the Year ${ }_{t}$ and \% Change in Real GDP. Merger waves are accounted for by the Number of M\&A Announced during the Year $_{t}$ and Dollar Value of M\&A Announced during the Year ${ }_{t}$. The two industry instruments represent the attractiveness of a given industry to (potential) conglomerates. Specifically, the measures are the Fraction of Industry Firms that are Multi-Industry ${ }_{i, t}$ and the Fraction of Industry Sales from Multi-Industry

Firms $s_{i, t}{ }^{37}$ See Appendix I for additional detail on the variable definitions.

I use an adjusted tax variable as the outcome of interest, Tax adjusted $_{i, t}$, which is demeaned by firm and year. ${ }^{38}$ Campa and Kedia (2002) explain that by using an adjusted outcome variable in this way the outcome variable is, by construction, uncorrelated with characteristics that affect the outcome of interest on these dimensions in the same manner (i.e. for a firm across all years or all firms in a given year in the same way). As a result, they expect that, by construction, the instruments are unlikely to be uncorrelated with $\varepsilon_{i, t}$. The authors conclude that given the variables above are expected to be reasonable predictors of a firm's diversification decision and are not expected to affect the outcome of interest (in its adjusted form) directly, then the above set of variables are valid instruments for this design. ${ }^{39}$ The

\footnotetext{
${ }^{37}$ I include one of the instruments used in Campa and Kedia (2002) in both equations (2) and (3) (i.e. use it as a control in both equations rather than as an instrument). The variable is an indicator for whether a firm is incorporated in a foreign country (Incorporated Outside the U.S. ${ }_{i, t}$ ). Given the prevalence of attention to multinational tax planning, I include this variable in both stages as part of $X_{i, t}$ to allow it to have both an indirect effect on firm taxes through the firm's diversification choice and a direct effect on taxes in the second stage.

${ }^{38}$ This is analogous to a firm and year fixed effect estimator used in the earlier tests.

${ }^{39}$ Larcker and Rusticus (2010) express concerns regarding the use of industry aggregates and lagged variables as instruments. I cannot rule out the authors' concerns for these variables with the aforementioned design. I include the the instrumental variable analysis for completeness as it has been used extensively in the diversification literature. However, following the recommendations of Larcker and Rusticus (2010), in my analysis using this design I include
} 
remaining variables in equations (2) and (3) Diversification ${ }_{i, t}$ and Controls $_{i, t}$ are defined in the same way as for equation (1).

The results for the 2SLS and treatment effects approaches are reported in Table 6. For ease of reference, I include the primary fixed effects OLS results from Table 2 in column (1) of Table 6 Panel A, given that these three methodologies are all commonly used in conjunction in the literature. ${ }^{40}$ The estimates from equation (2) (equation (3)) are reported in Panel A (Panel B). When comparing the results for my primary OLS specification with the results under these alternative simultaneous equations approaches, the coefficients on Diversification $_{i, t}$ in all three columns (for all three approaches) are negative and significant, supporting a consistent tax benefit on average from diversification across all three estimation approaches.

While I include the 2SLS and treatment effects models for completeness given their prevalence in the literature, I express caution when relying on the instrumental variable test inferences in place of the primary results given the results of several diagnostic tests I examine related to these tests. Wooldridge (2002) and Larcker and Rusticus (2010) recommend that researchers applying an instrumental variables design use a series of diagnostic tests to assess the appropriateness of the design for a specific research setting. Three tests they discuss are used to assess the validity of the set of instruments: an F-test examining the null that the instruments do not enter equation (1), an overidentification test of the null that the instruments are uncorrelated with the error term in equation (2), and a review of an R-squared in a first-stage regression to assess how well equation (1) explains the endogenous diversification choice. These tests of the validity of the instruments help assess whether the set of instruments: 1) are correlated with the diversification choice after accounting for other control variables and 2) are uncorrelated with the second stage residual. The final test is a Hausman test used to assess the null hypothesis that the OLS

a series of diagnostic tests on the use of these instruments in my setting. I note the caveats or limitations related to their concerns in the concluding statements from this analysis below.

${ }^{40}$ The 2SLS and treatment effects models are estimated with a maximum likelihood estimator. 
fixed effect specification is a consistent estimator for Diversification ${ }_{i, t}$ under the assumption that $2 \mathrm{SLS}$ is a consistent but inefficient estimator.

I report the results of the F-test, overidentification test, and the R-squared for the first stage regressions in Table 6 Panel B. The Hausman test is untabulated but is discussed below. Overall, the Ftest and the R-squared related to the first stage regression provide some evidence that the set of instruments are not weak in terms of their ability to predict a firm's diversification choice. However, the overidentification test suggests that it may not be valid to assume the instruments should be excluded from the second stage. Furthermore, the Hausman test does not allow me to reject the null of the exogeneity of Diversification ${ }_{i, t}$ in my primary OLS fixed effect specification in comparision with the 2SLS estimator.

Specifically, the F-statistics (p-values) reported in Table 6 Panel B columns (1) and (2) are 2,627 (0.000) and 1,715 (0.000), respectively, far exceeding the threshold for a weak instrument suggested in Staiger and Stock (1997). ${ }^{41}$ Further, the R-squared and pseudo R-squared for the first stages reported in columns (1) and (2) of 0.210 and 0.214 , respectively, suggest that equation (2) explains a meaningful

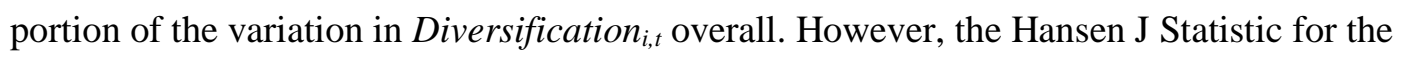
overidentification test reported in Panel A for column (1) allows a rejection of the null that the set of instruments are valid. ${ }^{42}$ Finally, a Hausman test comparing the OLS fixed effects specification to the 2SLS specification (untabulated) does not allow me to reject the null that the OLS fixed effects specification is a consistent estimator for my setting $(\mathrm{p}$-value $=0.174)$ in comparison with the 2 SLS estimation.

\footnotetext{
${ }^{41}$ The F-test used comes from Bound, Jaeger, and Baker (1995) and Staiger and Stock (1997). These studies suggest that the standard asymptotic approximations for instrumental variables breaks down when instruments are weak, where they offer an F-statistic less than ten as an indication of when the instruments are weak.

${ }^{42}$ The treatreg command in Stata does not support the overid post-estimation command, which is why I do not report an overidentification test statistic for the treatment effects model. However, the same set of instruments and outcome of interest are used in both the 2SLS and treatment effects models, suggesting the instruments would likely generate a similar inference from an overidentification test for the treatment effects specification.
} 
Overall, while the two instrumental variables techniques are conventional approaches to addressing endogeneity in the diversification literature, the results from the diagnostic tests in my setting are (at best) mixed, and do not allow me to rely on the instrumental variables approaches to rule out sources of endogeneity. Thus, I cannot rule out factors that are not addressed by inclusion of firm and year fixed effects in the OLS estimation (e.g. factors that can vary within the firm over time) that are also consistent with my cross-sectional test results.

However, it is important to note here that if the potentially unresolved endogeneity bias works in the direction of a tax cost from diversification (bias toward zero or a positive coefficient), then this bias should not alter the inferences based on the sign of the primary findings in this study, but instead indicate that the observed coefficient magnitudes for the tax benefit observed are understated. An obvious factor that could induce this form of bias based on the literature is whether a firm's risk strategy changes over time (is not addressed by firm fixed effects) and influences both a firm's decision to diversify and its tax liabilities. If a firm switches from a high to a lower risk strategy and diversifies as part of this change in strategy, I would expect the firm to either claim no additional tax benefits from diversification or perhaps even avoid less tax on average (generating a tax cost from diversification). Thus, to the extent that my design above does not account for this form of endogeneity, the tax benefit observed may be understated. 


\section{CHAPTER 5: CONCLUSION}

An extensive line of academic research spanning multiple decades, along with debates in practice, suggest that the value of corporate diversification as part of business strategy remains a puzzle. This paper takes a unique approach to examining corporate diversification by focusing on a specific predicted benefit from this literature (namely, additional tax savings) rather than the valuation effect overall. I find that, on average, firms operating in multiple industries have lower tax liabilities than single industry firms. However, where the additional tax benefits from diversification are expected to act as a substitute for tax positions already available, for firms that do not carry high financial constraints, or for firms without a high risk preference, I do not observe significant additional tax savings related to diversification. The combined set of results here provide greater understanding about the conditions under which a firm may obtain one of the key cited benefits from industrial diversification.

Like much of the diversification literature, the results in this study are subject to an important limitation. Ultimately, diversification is a strategy that firms decide whether or not to employ that is not assigned randomly. Thus, it is difficult to rule out the possibility that there are unobservable factors that relate to both this decision and firm tax liabilities. However, a plausible factor left unaccounted for in the design above (changes in firm risk strategy over time) likely induces a form of bias that would understate the tax benefit I observe. While this paper nor the literature more generally can rule out this limitation, my results suggest an interesting avenue for future research is to examine other, specific benefits (or costs) from diversification (e.g. leveraging research and innovation across multiple products and services) to inform the debate to help provide a greater understanding of why we observe success from diversification from some firms, but not others. 
TABLE 1: DESCRIPTIVE STATISTICS AND CORRELATION MATRIX

Panel A Full Sample Descriptive Statistics

\begin{tabular}{|c|c|c|c|c|c|c|}
\hline \multicolumn{4}{|l|}{ Variable } & $\mathbf{N}$ & Mean & Std dev \\
\hline \multicolumn{4}{|l|}{ Cash taxes paid/MVA ${ }_{i t}$} & 26910 & 0.0091 & 0.0130 \\
\hline \multicolumn{4}{|l|}{ Multiple industries $_{\text {it }}$} & 26910 & 0.1969 & 0.3976 \\
\hline \multicolumn{4}{|l|}{ \# of industries it } & 26229 & 1.2244 & 0.5204 \\
\hline \multicolumn{4}{|l|}{$\%$ sales in other industries it } & 25926 & 28.4220 & 42.8638 \\
\hline \multicolumn{4}{|l|}{ Sales-weighted distance ${ }_{i t}$} & 26098 & 0.4671 & 0.8050 \\
\hline \multicolumn{4}{|l|}{ No disclosure it } & 26910 & 0.9569 & 0.2030 \\
\hline \multicolumn{4}{|l|}{ Size $_{\text {it }}$} & 26910 & 5.0701 & 2.3750 \\
\hline \multicolumn{4}{|l|}{ Leverage $_{i t}$} & 26910 & 0.7824 & 1.8742 \\
\hline \multicolumn{4}{|l|}{ Market-to-book $k_{i t}$} & 26910 & 2.4106 & 6.3765 \\
\hline \multicolumn{4}{|l|}{ Tax loss carryforward ${ }_{i t}$} & 26910 & 0.6236 & 0.4845 \\
\hline \multicolumn{4}{|l|}{ Increase in tax loss carryforward it } & 26910 & 0.3878 & 0.4873 \\
\hline \multicolumn{4}{|l|}{ Pre-tax income it } & 26910 & -0.1654 & 1.2933 \\
\hline \multicolumn{4}{|l|}{ 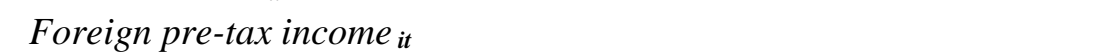 } & 26910 & 0.0054 & 0.0235 \\
\hline \multicolumn{4}{|l|}{$P P \& E_{i t}$} & 26910 & 0.2590 & 0.2899 \\
\hline \multicolumn{4}{|l|}{$R \& D_{i t}$} & 26910 & 0.0522 & 0.1343 \\
\hline \multicolumn{4}{|l|}{ Equity income $_{\text {it }}$} & 26910 & 0.0003 & 0.0026 \\
\hline \multicolumn{4}{|l|}{ Intangibles it } & 26910 & 0.1449 & 0.2260 \\
\hline \multicolumn{4}{|l|}{ Return volatility $_{i t}$} & 22223 & -3.4431 & 0.5520 \\
\hline \multicolumn{4}{|c|}{ SA Index $x_{i t}$} & 26884 & -3.0092 & 1.1128 \\
\hline \multicolumn{7}{|c|}{ Panel B Single and Multiple Industry Firm Descriptive Statistics } \\
\hline & \multicolumn{3}{|c|}{ Single industry firms } & \multicolumn{3}{|c|}{ Multiple industry firms } \\
\hline Variable & $\mathbf{N}$ & Mean & Std dev & $\mathbf{N}$ & Mean & Std dev \\
\hline Cash taxes paid/MVA ${ }_{i t}$ & 21612 & 0.0086 & 0.013 & 5298 & 0.0112 & 0.0131 \\
\hline No disclosure $i t$ & 21612 & 0.956 & 0.205 & 5298 & 0.9606 & 0.1947 \\
\hline Size $_{\text {it }}$ & 21612 & 4.8809 & 2.3581 & 5298 & 5.8421 & 2.2859 \\
\hline Leverage $_{i t}$ & 21612 & 0.8089 & 2.0569 & 5298 & 0.6742 & 0.7542 \\
\hline Market-to-book ${ }_{i t}$ & 21612 & 2.505 & 6.8154 & 5298 & 2.0254 & 4.1064 \\
\hline Tax loss carryforward ${ }_{i t}$ & 21612 & 0.6239 & 0.4844 & 5298 & 0.6227 & 0.4848 \\
\hline Increase in tax loss carryforward it & 21612 & 0.3922 & 0.4883 & 5298 & 0.3698 & 0.4828 \\
\hline Pre-tax income $_{i t}$ & 21612 & -0.2085 & 1.4256 & 5298 & 0.0104 & 0.4088 \\
\hline 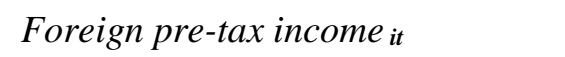 & 21612 & 0.0049 & 0.0235 & 5298 & 0.0077 & 0.0235 \\
\hline$P P \& E_{i t}$ & 21612 & 0.2465 & 0.2885 & 5298 & 0.3097 & 0.2902 \\
\hline$R \& D_{i t}$ & 21612 & 0.0612 & 0.1466 & 5298 & 0.0158 & 0.0479 \\
\hline Equity income $_{\text {it }}$ & 21612 & 0.0002 & 0.0023 & 5298 & 0.0006 & 0.0035 \\
\hline Intangibles it & 21612 & 0.1356 & 0.2226 & 5298 & 0.1832 & 0.2355 \\
\hline Return volatility $_{i t}$ & 17442 & -3.4081 & .5541 & 4781 & -3.5709 & 0.5250 \\
\hline SA Index ${ }_{i t}$ & 21586 & -2.8780 & 1.1342 & 5298 & -3.5437 & 0.8285 \\
\hline
\end{tabular}


TABLE 1: DESCRIPTIVE STATISTICS AND CORRELATION MATRIX - CONTINUED

Panel C Correlation Matrix

\begin{tabular}{|c|c|c|c|c|c|c|c|c|c|c|c|c|c|c|c|c|}
\hline & (1) & (2) & (3) & (4) & (5) & (6) & (7) & (8) & (9) & (10) & (11) & (12) & (13) & (14) & (15) & (16) \\
\hline (1) Cash taxes paid/MVA ${ }_{\text {it }}$ & & 0.07 & 0.06 & 0.05 & 0.00 & -0.01 & 0.15 & -0.11 & -0.01 & -0.33 & 0.16 & 0.08 & 0.01 & -0.16 & 0.04 & 0.03 \\
\hline (2) Multiple industries it & 0.13 & & 0.85 & 0.24 & 0.31 & 0.01 & 0.15 & -0.02 & -0.04 & 0.01 & 0.06 & 0.05 & 0.09 & -0.14 & 0.07 & 0.08 \\
\hline (3) \# of industries & 0.13 & 0.99 & & 0.25 & 0.32 & -0.01 & 0.18 & -0.01 & -0.03 & -0.00 & 0.05 & $0 .($ & 0.09 & -0.12 & 0.08 & 0.06 \\
\hline (4) $\%$ sales in other industries ${ }_{i t}$ & 0.09 & 0.46 & 0.47 & & 0.82 & 0.01 & -0.07 & 0.02 & $-\mathbf{0 . 0 3}$ & 0.01 & -0.04 & 0.01 & 0.06 & -0.11 & -0.00 & 0.07 \\
\hline (5) Sales-weighted distance it & 0.08 & 0.53 & 0.53 & 0.97 & & 0.01 & -0.09 & 0.04 & -0.02 & 0.02 & -0.07 & -0.01 & $\mathbf{0 . 0 3}$ & -0.08 & 0.01 & 0.05 \\
\hline (6) No disclosure it & -0.06 & 0.01 & 0.01 & 0.01 & 0.01 & & -0.07 & 0.02 & -0.00 & -0.09 & $-\mathbf{0 . 0 3}$ & -0.15 & 0.01 & -0.01 & -0.01 & -0.00 \\
\hline (7) Size $_{\text {it }}$ & & 0.15 & 0.16 & -0.02 & -0.01 & -0.07 & & -0.14 & 0.17 & -0.14 & 0.23 & 0.21 & 0.1 & -0.09 & 0.10 & 0.16 \\
\hline (8) Leverage $i t$ & -0.17 & 0.13 & 0.13 & 0.06 & 0.07 & 0.02 & $\mathbf{0 . 0 3}$ & & -0.09 & 0.07 & -0.56 & $-\mathbf{0 . 0 3}$ & -0.01 & 0.07 & -0.00 & 0.01 \\
\hline (9) Market-to-book $i t$ & 0.11 & -0.05 & -0.05 & -0.06 & -0.06 & -0.03 & 0.44 & -0.11 & & -0.01 & 0.09 & $\mathbf{0 . 0 3}$ & 0.01 & 0.10 & -0.01 & 0.01 \\
\hline (10) Tax loss carryforward ${ }_{i t}$ & -0.29 & 0.01 & 0.00 & 0.01 & 0.01 & -0.09 & -0.13 & 0.07 & -0.03 & & -0.14 & 0.06 & -0.07 & 0.21 & -0.05 & 0.15 \\
\hline (11) Pre-tax & 0.56 & 0.06 & 0.06 & 0.02 & 0.01 & -0.01 & 0.43 & -0.13 & 0.36 & -0.36 & & 0.06 & 0.04 & -0.22 & $\mathbf{0 . 0 3}$ & 0.03 \\
\hline (12) Foreign pre-tax income it & 0.18 & 0.08 & 0.08 & 0.03 & 0.03 & -0.14 & 0.25 & -0.03 & 0.12 & 0.07 & 0.22 & & -0.02 & -0.00 & 0.06 & 0.08 \\
\hline (13) $P P \& E_{i t}$ & 0.15 & 0.12 & 0.12 & 0.15 & 0.14 & -0.02 & 0.11 & 0.08 & 0.07 & -0.03 & 0.16 & 0.02 & & -0.17 & 0.03 & -0.15 \\
\hline (14) $R \& D_{i t}$ & -0.10 & -0.10 & -0.11 & -0.13 & -0.13 & -0.10 & -0.06 & -0.22 & 0.18 & 0.28 & -0.14 & 0.13 & -0.15 & & -0.06 & -0.02 \\
\hline (15) Equity income $i t$ & 0.05 & 0.09 & 0.09 & 0.02 & 0.03 & -0.02 & 0.15 & 0.07 & 0.01 & -0.06 & 0.08 & 0.08 & 0.01 & -0.08 & & 0.00 \\
\hline (16) Intangibles it & 0.18 & 0.15 & 0.14 & 0.11 & 0.11 & -0.04 & 0.22 & 0.05 & 0.12 & 0.17 & 0.10 & 0.18 & -0.02 & 0.08 & 0.03 & \\
\hline
\end{tabular}

Table 1 Panels A and B present the descriptive statistics for different samples. In Panel C, I report the Pearson (Spearman) correlation matrix above (below) the diagonal for the full sample. Statistical significance for correlations significant at the $10 \%$ level or better are bolded. See Appendix I for variable descriptions. All continuous variables are truncated at the $1^{\text {st }}$ and $99^{\text {th }}$ percentiles with the following exception. Variables with zero for many observations in the bottom of their distributions (e.g. $R \& D$ it and Foreign pre-tax income it) are truncated only at the top percentile. In Panel A, the number of observations differs for alternate continuous measures of diversification because the truncation for these continuous measures is not required for the primary sample. 
TABLE 2: OLS REGRESSIONS OF TAX ON DIFFERENT DIVERSIFICATION MEASURES

\begin{tabular}{|c|c|c|c|c|}
\hline \multirow[t]{2}{*}{ Dependent Variable: } & \multicolumn{4}{|c|}{ Cash taxes paid / MVA ${ }_{\text {it }}$} \\
\hline & (1) & (2) & (3) & (4) \\
\hline \multirow[t]{2}{*}{ Diversification $_{i t}$} & $-0.0013^{* *}$ & $-0.0008^{*}$ & $-0.0002 * *$ & $-0.0002 * *$ \\
\hline & $(-2.346)$ & $(-1.923)$ & $(-2.174)$ & $(-2.158)$ \\
\hline \multirow[t]{2}{*}{ No disclosure it } & 0.0031 & $0.0049 * * *$ & 0.0031 & 0.0031 \\
\hline & $(1.333)$ & $(3.657)$ & $(1.330)$ & $(1.293)$ \\
\hline \multirow[t]{2}{*}{ Size $_{i t}$} & $0.0008 * * *$ & $0.0007 * * *$ & $0.0008 * * *$ & $0.0008 * * *$ \\
\hline & $(6.251)$ & $(6.027)$ & $(6.158)$ & $(6.040)$ \\
\hline \multirow[t]{2}{*}{ Leverage $_{i t}$} & -0.0000 & -0.0000 & -0.0000 & -0.0000 \\
\hline & $(-0.133)$ & $(-0.149)$ & $(-0.351)$ & $(-0.341)$ \\
\hline \multirow[t]{2}{*}{ Market-to-book $_{i t}$} & $-0.0001 * * *$ & $-0.0001 * * *$ & $-0.0001 * * *$ & $-0.0001 * * *$ \\
\hline & $(-7.975)$ & $(-7.883)$ & $(-8.016)$ & $(-7.687)$ \\
\hline \multirow[t]{2}{*}{ Tax loss carryforward $_{i t}$} & $-0.0054 * * *$ & $-0.0056^{* * *}$ & $-0.0056 * * *$ & $-0.0055^{* * *}$ \\
\hline & $(-10.322)$ & $(-10.361)$ & $(-10.361)$ & $(-10.082)$ \\
\hline \multirow[t]{2}{*}{ Increase in tax loss carryforward it } & $-0.0009 * * *$ & $-0.0009 * * *$ & $-0.0008 * * *$ & $-0.0009 * * *$ \\
\hline & $(-4.787)$ & $(-4.703)$ & $(-4.564)$ & $(-4.839)$ \\
\hline \multirow[t]{2}{*}{ Pre-tax income it } & $0.0003 * * *$ & $0.0003^{* * *}$ & $0.0005 * * *$ & $0.0003^{* * *}$ \\
\hline & $(4.187)$ & $(4.062)$ & $(3.860)$ & $(3.763)$ \\
\hline \multirow[t]{2}{*}{ Foreign pre-tax income it } & 0.0068 & 0.0072 & 0.0063 & 0.0070 \\
\hline & $(1.394)$ & $(1.465)$ & $(1.285)$ & $(1.424)$ \\
\hline \multirow[t]{2}{*}{$P P \& E_{i t}$} & $-0.0030 * * *$ & $-0.0029 * * *$ & $-0.0032 * * *$ & $-0.0029 * * *$ \\
\hline & $(-4.360)$ & $(-4.244)$ & $(-4.077)$ & $(-4.039)$ \\
\hline \multirow[t]{2}{*}{$R \& D_{i t}$} & $-0.0017 * * *$ & $-0.0017 * * *$ & $-0.0021 * *$ & $-0.0016^{* *}$ \\
\hline & $(-2.643)$ & $(-2.666)$ & $(-2.502)$ & $(-2.285)$ \\
\hline \multirow[t]{2}{*}{ Equity income it } & $0.1068 * *$ & $0.0961 *$ & $0.1072 * *$ & $0.1134 * *$ \\
\hline & $(2.249)$ & $(1.932)$ & $(2.270)$ & $(2.239)$ \\
\hline \multirow[t]{2}{*}{ Intangibles it } & -0.0007 & -0.0007 & -0.0009 & -0.0007 \\
\hline & $(-1.301)$ & $(-1.199)$ & $(-1.469)$ & $(-1.258)$ \\
\hline \multirow[t]{2}{*}{ Intercept } & $0.0097 * * *$ & $0.0089 * * *$ & $0.0103 * * *$ & $0.0103 * * *$ \\
\hline & $(4.182)$ & $(5.854)$ & $(4.338)$ & $(4.291)$ \\
\hline Diversification measure: & $\begin{array}{c}\text { Multiple } \\
\text { industries it }\end{array}$ & $\begin{array}{c}\text { \# of } \\
\text { industries it }\end{array}$ & $\begin{array}{l}\text { \% sales in } \\
\text { other } \\
\text { industries it }\end{array}$ & $\begin{array}{l}\text { Sales- } \\
\text { weighted } \\
\text { distance }_{\text {it }}\end{array}$ \\
\hline Firm fixed effects & Yes & Yes & Yes & Yes \\
\hline Year fixed effects & Yes & Yes & Yes & Yes \\
\hline R-squared & 0.652 & 0.654 & 0.650 & 0.653 \\
\hline $\mathrm{N}$ & 26,910 & 26,229 & 25,926 & 26,098 \\
\hline \multicolumn{5}{|c|}{$\begin{array}{l}\text { Table } 2 \text { presents the estimates of equation (1). Columns (1)-(4) differ based on the measure of } \\
\text { Diversification }{ }_{i t} \text { used. Standard errors are robust and clustered by firm, and t-statistics are in parentheses. } \\
\text { I define the variables in Appendix I. The symbols } * * *, * * \text {, and } * \text { denote statistical significance at the } \\
1 \%, 5 \% \text { and } 10 \% \text { levels (two-tailed), respectively. }\end{array}$} \\
\hline
\end{tabular}


TABLE 3: EFFECT OF DIVERSIFICATION WITH VARIED R\&D ACTIVITY

\begin{tabular}{|c|c|c|c|}
\hline \multirow[t]{2}{*}{ Dependent Variable: } & \multicolumn{3}{|c|}{ Cash taxes paid / MVA $A_{i t}$} \\
\hline & $\begin{array}{l}\text { Low } \\
R \& D\end{array}$ & $\begin{array}{c}\text { Moderate } \\
R \& D\end{array}$ & $\begin{array}{l}\text { High } \\
R \& D\end{array}$ \\
\hline & $(1)$ & $(2)$ & $(3)$ \\
\hline Diversification $_{\text {it }}$ & $\begin{array}{l}-0.0013 * * \\
(-2.110)\end{array}$ & $\begin{array}{c}-0.0031 \\
(-1.464)\end{array}$ & $\begin{array}{c}0.0056 \\
(1.582)\end{array}$ \\
\hline No disclosure ${ }_{i t}$ & $\begin{array}{l}0.0025^{* * *} \\
(3.402)\end{array}$ & $\begin{array}{r}0.0021 \\
(0.754)\end{array}$ & \\
\hline Size $_{i t}$ & $\begin{array}{l}0.0011^{* * * *} \\
(7.126)\end{array}$ & $\begin{array}{c}-0.0004 \\
(-1.197)\end{array}$ & $\begin{array}{c}-0.0002 \\
(-0.901)\end{array}$ \\
\hline Leverage $_{\text {it }}$ & $\begin{array}{c}0.0000 \\
(0.280)\end{array}$ & $\begin{array}{r}-0.0005 \\
(-0.763)\end{array}$ & $\begin{array}{c}-0.0000 \\
(-0.107)\end{array}$ \\
\hline Market-to-book $_{i t}$ & $\begin{array}{l}-0.0001 * * * \\
(-6.118)\end{array}$ & $\begin{array}{l}-0.0001 \text { *** } \\
(-3.377)\end{array}$ & $\begin{array}{l}-0.0000 * * \\
(-2.121)\end{array}$ \\
\hline Tax loss carryforward it & $\begin{array}{l}-0.0052 * * * \\
(-8.477)\end{array}$ & $\begin{array}{l}-0.0056^{* * * *} \\
(-4.076)\end{array}$ & $\begin{array}{l}-0.0049 * * \\
(-2.025)\end{array}$ \\
\hline Increase in tax loss carryforward it & $\begin{array}{l}-0.0011 * * * \\
(-4.581)\end{array}$ & $\begin{array}{c}-0.0003 \\
(-0.628)\end{array}$ & $\begin{array}{c}0.0002 \\
(0.576)\end{array}$ \\
\hline Pre-tax income it & $\begin{array}{l}0.0004^{* * *} \\
(5.008)\end{array}$ & $\begin{array}{l}0.0032^{* * *} \\
(3.418)\end{array}$ & $\begin{array}{c}-0.0001 \\
(-0.667)\end{array}$ \\
\hline 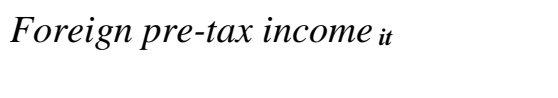 & $\begin{array}{l}0.0140 * \\
(1.850)\end{array}$ & $\begin{array}{c}-0.0092 \\
(-1.141)\end{array}$ & $\begin{array}{c}-0.0040 \\
(-0.401)\end{array}$ \\
\hline$P P \& E_{i t}$ & $\begin{array}{l}-0.0032 * * * \\
(-4.270)\end{array}$ & $\begin{array}{c}0.0008 \\
(0.252)\end{array}$ & $\begin{array}{c}0.0005 \\
(0.250)\end{array}$ \\
\hline$R \& D_{i t}$ & $\begin{array}{c}-0.0312 \\
(-1.017)\end{array}$ & $\begin{array}{c}-0.0103 \\
(-1.208)\end{array}$ & $\begin{array}{c}-0.0004 \\
(-0.608)\end{array}$ \\
\hline Equity income it & $\begin{array}{l}0.1179 * * \\
(2.163)\end{array}$ & $\begin{array}{r}0.0063 \\
(0.058)\end{array}$ & $\begin{array}{r}0.0375 \\
(0.417)\end{array}$ \\
\hline Intangibles it & $\begin{array}{l}-0.0010 \\
(-1.208)\end{array}$ & $\begin{array}{c}-0.0014 \\
(-1.088)\end{array}$ & $\begin{array}{l}-0.0003 \\
(-0.332)\end{array}$ \\
\hline Intercept & $\begin{array}{l}0.0099 \text { *** } \\
(10.143)\end{array}$ & $\begin{array}{l}0.0158^{* * * *} \\
(4.299)\end{array}$ & $\begin{array}{l}0.0084 * * * \\
(4.527)\end{array}$ \\
\hline Firm fixed effects & Yes & Yes & Yes \\
\hline Year fixed effects & Yes & Yes & Yes \\
\hline R-squared & 0.657 & 0.629 & 0.637 \\
\hline $\mathrm{N}$ & 20,638 & 4,008 & 2,264 \\
\hline
\end{tabular}

Table 3 presents the estimates of equation (1) across firms with increasing values of the size-age index from Hadlock and Pierce (2010) in columns (1)-(3), respectively. Standard errors are robust and clustered by firm, and t-statistics are in parentheses. I define the variables in Appendix I. The symbols $* * *, * *$, and $*$ denote statistical significance at the $1 \%, 5 \%$ and $10 \%$ levels (two-tailed), respectively. 
TABLE 4: EFFECT OF DIVERSIFICATION WITH VARIED FINANCIAL CONSTRAINTS

\begin{tabular}{|c|c|c|c|}
\hline \multirow[t]{2}{*}{ Dependent Variable: } & \multicolumn{3}{|c|}{ Cash taxes paid / MVA $A_{i t}$} \\
\hline & $\begin{array}{c}\text { Low } \\
\text { Constraints }\end{array}$ & $\begin{array}{l}\text { Moderate } \\
\text { Constraints }\end{array}$ & $\begin{array}{c}\text { High } \\
\text { Constraints }\end{array}$ \\
\hline & $(1)$ & $(2)$ & (3) \\
\hline Diversification $_{\text {it }}$ & $\begin{array}{c}-0.0001 \\
(-0.153)\end{array}$ & $\begin{array}{l}-0.0015 \\
(-1.410)\end{array}$ & $\begin{array}{l}-0.0025 * * \\
(-2.208)\end{array}$ \\
\hline No disclosure ${ }_{i t}$ & $\begin{array}{l}-0.0029 * * * \\
(-6.696)\end{array}$ & $\begin{array}{l}0.0056^{* * * *} \\
(10.127)\end{array}$ & \\
\hline Size $_{i t}$ & $\begin{array}{l}0.0006^{* *} \\
(2.085)\end{array}$ & $\begin{array}{l}0.0005^{* *} \\
(2.372)\end{array}$ & $\begin{array}{c}0.0003 \\
(1.522)\end{array}$ \\
\hline Leverage $_{i t}$ & $\begin{array}{l}-0.0023 * * * \\
(-2.594)\end{array}$ & $\begin{array}{l}-0.0011 * * * \\
(-2.735)\end{array}$ & $\begin{array}{l}-0.0000 \\
(-1.511)\end{array}$ \\
\hline Market-to-book $_{i t}$ & $\begin{array}{l}-0.0002 * * * \\
(-4.408)\end{array}$ & $\begin{array}{l}-0.0002 * * * \\
(-5.650)\end{array}$ & $\begin{array}{l}-0.0000 * * * \\
(-3.061)\end{array}$ \\
\hline Tax loss carryforward it & $\begin{array}{l}-0.0032 * * * \\
(-4.223)\end{array}$ & $\begin{array}{l}-0.0053 * * * \\
(-6.286)\end{array}$ & $\begin{array}{l}-0.0081 * * * \\
(-7.063)\end{array}$ \\
\hline Increase in tax loss carryforward it & $\begin{array}{c}-0.0003 \\
(-0.818)\end{array}$ & $\begin{array}{l}-0.0003 \\
(-0.818)\end{array}$ & $\begin{array}{l}-0.0009 * * * \\
(-3.177)\end{array}$ \\
\hline Pre-tax income it & $\begin{array}{l}0.0189 \text { *** } \\
(3.592)\end{array}$ & $\begin{array}{l}0.0078^{* * *} \\
(6.056)\end{array}$ & $\begin{array}{c}0.0000 \\
(0.790)\end{array}$ \\
\hline 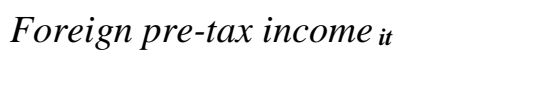 & $\begin{array}{c}-0.0070 \\
(-0.727)\end{array}$ & $\begin{array}{l}-0.0063 \\
(-0.943)\end{array}$ & $\begin{array}{c}0.0126 \\
(1.151)\end{array}$ \\
\hline$P P \& E_{i t}$ & $\begin{array}{c}-0.0026 \\
(-1.523)\end{array}$ & $\begin{array}{l}-0.0022^{*} \\
(-1.696)\end{array}$ & $\begin{array}{l}-0.0037 \text { *** } \\
(-4.251)\end{array}$ \\
\hline$R \& D_{i t}$ & $\begin{array}{c}0.0020 \\
(0.366)\end{array}$ & $\begin{array}{r}0.0029 \\
(1.260)\end{array}$ & $\begin{array}{l}-0.0005 \\
(-0.848)\end{array}$ \\
\hline Equity income it & $\begin{array}{c}0.0660 \\
(1.153)\end{array}$ & $\begin{array}{c}0.0833 \\
(0.826)\end{array}$ & $\begin{array}{l}0.1412^{*} \\
(1.727)\end{array}$ \\
\hline Intangibles it & $\begin{array}{c}-0.0005 \\
(-0.393)\end{array}$ & $\begin{array}{l}-0.0006 \\
(-0.580)\end{array}$ & $\begin{array}{l}-0.0002 \\
(-0.227)\end{array}$ \\
\hline Intercept & $\begin{array}{l}0.0150 * * * \\
(7.707)\end{array}$ & $\begin{array}{l}0.0093^{* * *} \\
(6.238)\end{array}$ & $\begin{array}{l}0.0146^{* * * *} \\
(11.478)\end{array}$ \\
\hline Firm fixed effects & Yes & Yes & Yes \\
\hline Year fixed effects & Yes & Yes & Yes \\
\hline R-squared & 0.660 & 0.652 & 0.651 \\
\hline $\mathrm{N}$ & 8,974 & 10,663 & 7,256 \\
\hline
\end{tabular}

Table 4 presents the estimates of equation (1) across firms with increasing values of the size-age index from Hadlock and Pierce (2010) in columns (1)-(3), respectively. Standard errors are robust and clustered by firm, and t-statistics are in parentheses. I define the variables in Appendix I. The symbols $* * *, * *$, and $*$ denote statistical significance at the $1 \%, 5 \%$ and $10 \%$ levels (two-tailed), respectively. 
TABLE 5: EFFECT OF DIVERSIFICATION WITH VARIED FIRM RISK

\begin{tabular}{|c|c|c|c|}
\hline \multirow[t]{3}{*}{ Dependent Variable: } & \multicolumn{3}{|c|}{ Cash taxes paid / MVA ${ }_{i t}$} \\
\hline & $\begin{array}{l}\text { Low } \\
\text { Risk }\end{array}$ & Moderate & High \\
\hline & Risk & Risk & Risk \\
\hline & (1) & $(2)$ & (3) \\
\hline Diversification $_{\text {it }}$ & $\begin{array}{c}0.0000 \\
(0.035)\end{array}$ & $\begin{array}{c}-0.0008 \\
(-0.807)\end{array}$ & $\begin{array}{l}-0.0035^{* * *} \\
(-3.085)\end{array}$ \\
\hline No disclosure $_{i t}$ & & $\begin{array}{l}0.0076^{* * * *} \\
(5.182)\end{array}$ & $\begin{array}{l}0.0049 \text { *** } \\
(9.189)\end{array}$ \\
\hline Size $_{i t}$ & $\begin{array}{c}0.0005 \\
(1.534)\end{array}$ & $\begin{array}{c}0.0005 \\
(1.491)\end{array}$ & $\begin{array}{l}0.0006^{* * *} \\
(3.373)\end{array}$ \\
\hline Leverage $_{\text {it }}$ & $\begin{array}{l}-0.0010^{*} \\
(-1.647)\end{array}$ & $\begin{array}{l}-0.0026 * * * \\
(-3.015)\end{array}$ & $\begin{array}{c}-0.0003 \\
(-1.017)\end{array}$ \\
\hline Market-to-book ${ }_{i t}$ & $\begin{array}{c}-0.0001 * * * \\
(-3.348)\end{array}$ & $\begin{array}{l}-0.0003 * * * \\
(-5.296)\end{array}$ & $\begin{array}{l}-0.0001 * * * \\
(-4.154)\end{array}$ \\
\hline Tax loss carryforward ${ }_{\text {it }}$ & $\begin{array}{l}-0.0018^{* *} \\
(-1.987)\end{array}$ & $\begin{array}{l}-0.0065 * * * \\
(-7.517)\end{array}$ & $\begin{array}{l}-0.0060 \text { *** } \\
(-5.638)\end{array}$ \\
\hline Increase in tax loss carryforward it & $\begin{array}{l}-0.0008^{*} \\
(-1.821)\end{array}$ & $\begin{array}{c}-0.0001 \\
(-0.204)\end{array}$ & $\begin{array}{l}-0.0006^{*} \\
(-1.949)\end{array}$ \\
\hline Pre-tax income it & $\begin{array}{c}0.0225^{* * * *} \\
(3.946)\end{array}$ & $\begin{array}{l}0.0119 * * * \\
(4.606)\end{array}$ & $\begin{array}{c}0.0003 \\
(1.164)\end{array}$ \\
\hline Foreign pre-tax income $_{i t}$ & $\begin{array}{r}-0.0127 \\
(-1.148)\end{array}$ & $\begin{array}{c}0.0004 \\
(0.053)\end{array}$ & $\begin{array}{l}-0.0001 \\
(-0.016)\end{array}$ \\
\hline$P P \& E_{i t}$ & $\begin{array}{r}-0.0029 \\
(-1.607)\end{array}$ & $\begin{array}{l}-0.0026 \\
(-1.461)\end{array}$ & $\begin{array}{l}-0.0026 * * \\
(-2.299)\end{array}$ \\
\hline$R \& D_{i t}$ & $\begin{array}{r}0.0021 \\
(0.205)\end{array}$ & $\begin{array}{l}0.0088 * * \\
(2.378)\end{array}$ & $\begin{array}{c}-0.0005 \\
(-0.499)\end{array}$ \\
\hline Equity income it $_{\text {it }}$ & $\begin{array}{c}0.0852 \\
(1.219)\end{array}$ & $\begin{array}{c}0.1304 \\
(1.378)\end{array}$ & $\begin{array}{c}0.0765 \\
(0.802)\end{array}$ \\
\hline Intangibles it & $\begin{array}{l}-0.0033 * * \\
(-1.994)\end{array}$ & $\begin{array}{l}0.0020^{*} \\
(1.715)\end{array}$ & $\begin{array}{l}-0.0015^{*} \\
(-1.664)\end{array}$ \\
\hline Intercept & $\begin{array}{c}0.0127 * * * \\
(6.248)\end{array}$ & $\begin{array}{l}0.0098^{* * * *} \\
(4.922)\end{array}$ & $\begin{array}{l}0.0056^{* * *} \\
(3.748)\end{array}$ \\
\hline Firm fixed effects & Yes & Yes & Yes \\
\hline Year fixed effects & Yes & Yes & Yes \\
\hline R-squared & 0.685 & 0.624 & 0.607 \\
\hline $\mathrm{N}$ & 7,971 & 8,279 & 6,404 \\
\hline
\end{tabular}

Table 5 presents the estimates of equation (1) across different partitions of firm return volatility. Standard errors are robust and clustered by firm, and t-statistics are in parentheses. I define the variables in Appendix I. The symbols $* * *, * *$, and $*$ denote statistical significance at the $1 \%, 5 \%$ and $10 \%$ levels (two-tailed), respectively. 
TABLE 6: COMPARING TWO IV APPROACHES TO OLS ANALYSIS

\begin{tabular}{|c|c|c|c|}
\hline \multicolumn{2}{|l|}{ Panel A OLS and Second Stages } & \multirow{2}{*}{\multicolumn{2}{|c|}{$\begin{array}{l}\text { Cash taxes paid / } \\
M V A_{\text {it }}-\text { Adjusted }\end{array}$}} \\
\hline \multirow[t]{4}{*}{ Dependent Variable: } & $\begin{array}{c}\text { Cash taxes paid / } \\
M V A_{i t}\end{array}$ & & \\
\hline & & & Treatment \\
\hline & OLS & 2SLS & Effects \\
\hline & $(1)$ & $(2)$ & $(3)$ \\
\hline \multirow[t]{2}{*}{ Diversification $_{\text {it }}$} & $-0.0013 * *$ & $-0.0021 * * *$ & $-0.0017 * * *$ \\
\hline & $(-2.346)$ & $(-4.455)$ & $(-4.161)$ \\
\hline \multirow[t]{2}{*}{ No disclosure it } & 0.0031 & 0.0001 & 0.0000 \\
\hline & $(1.333)$ & $(0.374)$ & $(0.262)$ \\
\hline \multirow[t]{2}{*}{ Size $_{\text {it }}$} & $0.0008 * * *$ & $0.0002 * * *$ & $0.0002 * * *$ \\
\hline & $(6.251)$ & $(4.870)$ & $(4.597)$ \\
\hline \multirow[t]{2}{*}{ Leverage it } & -0.0000 & -0.0000 & -0.0000 \\
\hline & $(-0.133)$ & $(-0.773)$ & $(-0.800)$ \\
\hline \multirow[t]{2}{*}{ Market-to-book $_{i t}$} & $-0.0001 * * *$ & $-0.0000 * * *$ & $-0.0000 * * *$ \\
\hline & $(-7.975)$ & $(-5.910)$ & $(-5.800)$ \\
\hline \multirow[t]{2}{*}{ Tax loss carryforward ${ }_{i t}$} & $-0.0054 * * *$ & 0.0001 & 0.0001 \\
\hline & $(-10.322)$ & $(0.577)$ & $(0.503)$ \\
\hline \multirow[t]{2}{*}{ Increase in tax loss carryforward it } & $-0.0009 * * *$ & $-0.0008 * * *$ & $-0.0008 * * *$ \\
\hline & $(-4.787)$ & $(-5.090)$ & $(-5.096)$ \\
\hline \multirow[t]{2}{*}{ Pre-tax income it } & $0.0003 * * *$ & $-0.0001 *$ & $-0.0001 *$ \\
\hline & $(4.187)$ & $(-1.701)$ & $(-1.784)$ \\
\hline \multirow[t]{2}{*}{ 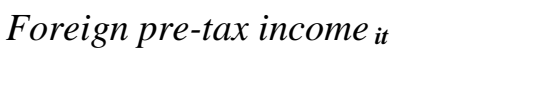 } & 0.0068 & 0.0004 & 0.0003 \\
\hline & $(1.394)$ & $(0.150)$ & $(0.113)$ \\
\hline \multirow[t]{2}{*}{$P P \& E_{i t}$} & $-0.0030 * * *$ & -0.0001 & -0.0002 \\
\hline & $(-4.360)$ & $(-0.711)$ & $(-0.915)$ \\
\hline \multirow[t]{2}{*}{$R \& D_{i t}$} & $-0.0017 * * *$ & -0.0001 & 0.0001 \\
\hline & $(-2.643)$ & $(-0.151)$ & $(0.136)$ \\
\hline \multirow[t]{2}{*}{ Equity income it } & $0.1068^{* *}$ & $0.0514 * *$ & $0.0481 * *$ \\
\hline & $(2.249)$ & $(2.260)$ & $(2.131)$ \\
\hline \multirow[t]{2}{*}{ Intangibles it } & -0.0007 & 0.0007 & 0.0007 \\
\hline & $(-1.301)$ & $(1.587)$ & $(1.501)$ \\
\hline \multirow[t]{2}{*}{ Incorporated Outside U.S. it } & & $-0.0004 * *$ & $-0.0004 * *$ \\
\hline & & $(-2.396)$ & $(-2.340)$ \\
\hline \multirow[t]{2}{*}{ Intercept } & $0.0097 * * *$ & $-0.0096 * * *$ & $-0.0096^{* * *}$ \\
\hline & $(4.182)$ & $(-33.171)$ & $(-33.431)$ \\
\hline $\mathrm{N}$ & 26,910 & 26,905 & 26,905 \\
\hline
\end{tabular}


TABLE 6: COMPARING TWO IV APPROACHES TO OLS ANALYSIS - CONTINUED

\begin{tabular}{|c|c|c|c|c|}
\hline \multicolumn{5}{|l|}{ Panel B First Stages } \\
\hline \multirow[t]{3}{*}{ Dependent Variable: } & \multicolumn{4}{|c|}{ Diversification $_{\text {it }}$} \\
\hline & \multicolumn{2}{|c|}{$\begin{array}{c}\text { (1) 2SLS } \\
\text { (Linear Probability) }\end{array}$} & \multicolumn{2}{|c|}{$\begin{array}{l}\text { (2) Treatment Effects } \\
\text { (Probit) }\end{array}$} \\
\hline & Coefficient & t-stat & Coefficient & z-stat \\
\hline \multicolumn{5}{|l|}{ Campa and Kedia (2002) Instruments } \\
\hline$S \& P$ Index $x_{i t}$ & $0.0993 * * *$ & $(3.77)$ & $0.3013 * * *$ & $(3.495$ \\
\hline Listed on a Major Stock Index $x_{i t}$ & 0.0065 & $(0.48)$ & 0.0477 & $(0.763)$ \\
\hline \# of Contraction Months during the Year & $0.0017 *$ & $(1.93)$ & $0.0099 * *$ & $(2.493)$ \\
\hline \# of Contraction Months during the Year $r_{t-1}$ & 0.0015 & $(1.51)$ & $0.0084 *$ & $(1.900)$ \\
\hline$\%$ Change in Real GDP & 0.0024 & $(0.94)$ & 0.0105 & $(0.897)$ \\
\hline$\%$ Change in Real GDP $P_{t-1}$ & 0.0015 & $(0.92)$ & 0.0084 & $(1.054)$ \\
\hline Number of M\&A Announced during the Year $_{t}$ & -0.0000 & $(-0.86)$ & -0.0000 & $(-1.562)$ \\
\hline Dollar Value of M\&A Announced during the Year & 0.0000 & $(1.31)$ & $0.0001 * *$ & $(2.043)$ \\
\hline Fraction of Industry Firms that are Multi-Industy ${ }_{i t}$ & $0.8594 * * *$ & $(24.69)$ & $3.0401 * * *$ & $(22.220)$ \\
\hline $\begin{array}{l}\text { Fraction of Industry Sales from Multi-Industry Firms } i t \\
\text { Second Stage Variables }\end{array}$ & \multicolumn{3}{|c|}{ Second Stage Variables } & $(0.834)$ \\
\hline No disclosure ${ }_{i t}$ & $0.0702 * *$ & $(2.51)$ & $0.2686^{* *}$ & $(2.002)$ \\
\hline Size $_{i t}$ & $0.0183 * * *$ & $(6.43)$ & $0.0681 * * *$ & $(5.201)$ \\
\hline Leverage $_{i t}$ & -0.0005 & $(-0.40)$ & -0.0146 & $(-1.082)$ \\
\hline Market-to-book & $-0.0020 * * *$ & $(-5.39)$ & $-0.0110 * * *$ & $(-4.372)$ \\
\hline Tax loss carryforward $_{i t}$ & $0.0443 * * *$ & $(3.94)$ & $0.2164 * * *$ & $(4.420)$ \\
\hline Increase in tax loss carryforward $_{\text {it }}$ & -0.0034 & $(-0.51)$ & -0.0035 & $(-0.116)$ \\
\hline Pre-tax income $e_{i t}$ & 0.0030 & $(1.63)$ & $0.0515^{* *}$ & $(2.227)$ \\
\hline Foreign pre-tax income $i t$ & -0.0329 & $(-0.19)$ & 0.1319 & $(0.172)$ \\
\hline$P P \& E_{i t}$ & 0.0219 & $(1.23)$ & $0.1474 * *$ & $(1.982)$ \\
\hline$R \& D_{i t}$ & $-0.1106 * * *$ & $(-6.11)$ & $-1.6184 * * *$ & $(-4.907)$ \\
\hline Equity income $_{i t}$ & $4.6468 * * *$ & $(2.82)$ & $13.5915^{* *}$ & $(2.242)$ \\
\hline Intangiblesit $_{\text {it }}$ & $0.0576^{* * *}$ & $(2.95)$ & $0.2960 * * *$ & $(3.769)$ \\
\hline Incorporated Outside U.S. it $_{\text {t }}$ & 0.0026 & $(0.15)$ & 0.0025 & $(0.032)$ \\
\hline Intercept & $-0.2282 * * *$ & $(-4.89)$ & $-2.5866 * * *$ & $(-11.378)$ \\
\hline $\begin{array}{l}\text { F-test of first stage IVs (F-statistic) } \\
\text { (p-value) }\end{array}$ & $2,627 * * *$ & & $1,715 * * *$ & \\
\hline Overidentification test (Hansen $\mathbf{J}$ statistic) & $209.713 * * *$ & & $\begin{array}{c}(0.0000) \\
-\end{array}$ & \\
\hline (p-value) & $(0.0000)$ & & - & \\
\hline R-squared (2SLS)/Pseudo R-squared (Treatment) & 0.210 & & 0.214 & \\
\hline $\mathrm{N}$ & 26,905 & & 29,905 & \\
\hline
\end{tabular}

Table 6 Panel A presents the OLS results from Table 2, 2SLS, and treatment effects estimations in columns (1)-(3), respectively. The 2SLS and treatment effects estimations use an adjusted tax measure that is demeaned by firm and year. See Appendix I for variable descriptions. The instrumental variables (exclusion restrictions) used for the 2SLS and treatment effects models are drawn from Campa and Kedia (2002). The only change I make to the set of instruments is to include Incorporated Outside the U.S. in both stages rather than as an instrument (i.e. rather than assume it has no direct effect on firm taxes after accounting for the control variables in the second stage). Panel B presents the first stages of the 2SLS and treatment effects models in columns (1) and (2), respectively. T-statistics/Z-statistics are in parentheses. Standard errors are robust and clustered by firm. Variables are defined in Appendix I. The symbols $* * *, * *$, and $*$ denote significance at the $1 \%, 5 \%$ and $10 \%$ levels, respectively. 


\section{APPENDIX: VARIABLE DESCRIPTIONS}

Tax $_{i t}$ proxies $^{43}$

\begin{tabular}{|l|l|}
\hline Cash taxes paid/MVA & $\begin{array}{l}\text { Cash taxes paid (TXPD) divided by the market value of assets. The } \\
\text { market value of assets equals total assets (AT) plus the product of } \\
\text { share price and common shares outstanding (PRCC_F x CSHO) less } \\
\text { stockholders equity (SEQ), based on the definition of the market value } \\
\text { of assets in Henry and Sansing (2015). }\end{array}$ \\
\hline $\begin{array}{l}\text { Cash taxes paid/MVA }{ }_{\text {it }}- \\
\text { Adjusted }\end{array}$ & Cash taxes paid/MVA $A_{\text {it }}$ demeaned by year and firm. \\
\hline
\end{tabular}

Diversification $_{\text {it }}$ proxies (segment data from Compustat historical segment database)

\begin{tabular}{|c|c|}
\hline Multiple industries & $\begin{array}{l}\text { An indicator equal to one if the number of industries (based on primary } \\
\text { four digit SIC codes (SICS1)) reported is greater than one; zero } \\
\text { otherwise }\end{array}$ \\
\hline \# of industries & $\begin{array}{l}\text { The number of industries (based on four digit primary SIC codes) } \\
\text { reported per firm-year }\end{array}$ \\
\hline$\%$ sales in other industries ${ }_{i t}$ & $\begin{array}{l}\text { The percent of total segment sales (sum of SALES) that are in different } \\
\text { industries (based on primary four digit SIC codes (SICS1)) than the } \\
\text { firm's industry }\end{array}$ \\
\hline Sales-weighted distance $_{i t}$ & $\begin{array}{l}\text { I first calculate the "distance" of each reported industry unit within a } \\
\text { firm. Distance is defined based on the idea of relatedness in Khorana et } \\
\text { al. (2011). If a reported industry in the segment data (SICS1) is in the } \\
\text { same four digit SIC code as the firm (SIC), it has a distance }=0 \text {. If it is } \\
\text { in the same three digit SIC code but not the same four digit SIC code, } \\
\text { its distance }=1 . \text { If it has the same two digit SIC code but not the same } \\
\text { three digit SIC code, its distance }=2 \text {. If it has the same one digit SIC } \\
\text { code but not the same two digit SIC code, its distance }=3 \text {. If it does not } \\
\text { have the same one digit SIC code, then its distance }=4 \text {. I then weight } \\
\text { each industry unit's distance by industry unit sales (SALES) to get an } \\
\text { overall weighted-sales distance measure for each firm-year }\end{array}$ \\
\hline
\end{tabular}

\section{Control and Cross-Sectional Test Variables}

\begin{tabular}{|c|c|}
\hline No disclosure it & $\begin{array}{l}\text { An indicator equal to one for observations that do not disclose } \\
\text { geographic earnings in the post-SFAS } 131 \text { period; zero otherwise, } \\
\text { following Hope et al. (2013). If missing, it is set equal to one }\end{array}$ \\
\hline Size $_{\text {it }}$ & $\begin{array}{l}\text { The natural log of the product of share price and common shares } \\
\text { outstanding (PRCC_F x CSHO) }\end{array}$ \\
\hline Leverage $_{\text {it }}$ & Total liabilities (LT) divided by lagged total assets (AT) \\
\hline Market-to-book it & $\begin{array}{l}\text { The product of share price and common shares outstanding (PRCC_F } \\
\mathrm{x} \text { CSHO) divided by common/ordinary equity (CEQ) }\end{array}$ \\
\hline Tax loss carryforward ${ }_{i t}$ & $\begin{array}{l}\text { An indicator equal to one if tax loss carryforward (TLCF) is positive; } \\
\text { set equal to zero otherwise }\end{array}$ \\
\hline $\begin{array}{l}\text { Increase in tax loss } \\
\text { carryforward } \\
\text { it }\end{array}$ & $\begin{array}{l}\text { An indicator equal to one if tax loss carryforward (TLCF) is greater in } \\
\text { the current year than in the prior year; set equal to zero otherwise }\end{array}$ \\
\hline 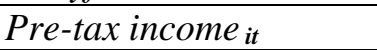 & Pre-tax income (PI) divided by lagged total assets (AT) \\
\hline
\end{tabular}

\footnotetext{
${ }^{43}$ Variables throughout reference Compustat Fundamentals Annual database unless another data source is explicitly referenced in the description.
} 


\begin{tabular}{|c|c|}
\hline Foreign pre-tax income $_{\text {it }}$ & $\begin{array}{l}\text { Pre-tax foreign income (PIFO) divided by lagged total assets (AT) } \\
\text { where missing values of PIFO are set equal to zero }\end{array}$ \\
\hline$P P \& E_{i t}$ & $\begin{array}{l}\text { Property, plant, and equipment (PPENT) divided by lagged total assets } \\
\text { (AT) where missing values of PPENT are set equal to zero }\end{array}$ \\
\hline$R \& D_{i t}$ & $\begin{array}{l}\text { Research and development expense (XRD) divided by lagged total } \\
\text { assets (AT) where missing values of XRD are set equal to zero }\end{array}$ \\
\hline Equity income $_{i t}$ & $\begin{array}{l}\text { Equity in earnings (ESUB) divided by lagged total assets (AT) where } \\
\text { missing values of ESUB are set equal to zero }\end{array}$ \\
\hline Intangibles it & $\begin{array}{l}\text { Intangible assets (INTAN) divided by lagged total assets (AT) where } \\
\text { missing values of INTAN are set equal to zero }\end{array}$ \\
\hline Return Volatility ${ }_{i t}$ & $\begin{array}{l}\text { The natural log of the standard deviation of daily stock returns for the } \\
\text { firm over the } 12 \text { months leading up to fiscal year-end (CRDP.DSF } \\
\text { variable RETX) }\end{array}$ \\
\hline SA Index ${ }_{i t}$ & $\begin{array}{l}\text { Similar to Hadlock and Pierce (2010): equals }-0.737 \times \text { Xize_HP }{ }_{i t}+ \\
0.043 \times \text { X Size_HP }{ }_{i t}^{2}-0.040 \times \text { x Age_HP }{ }_{i t} \text { where Size_HP }{ }_{i t} \text { equals the } \\
\text { natural log of total assets and age equals the difference between the } \\
\text { current year } t \text { and the first year in Compustat (YEAR1). Following } \\
\text { Hadlock and Pierce (2010), total assets is set equal to } \$ 4.5 \text { billion if it } \\
\text { exceeds this value when determining Size_HP }{ }_{i t} \text {, and } A g e_{-} H P_{i t} \text { is set } \\
\text { equal to } 37 \text { for values greater than } 37 \text {. }\end{array}$ \\
\hline
\end{tabular}

\section{Campa and Kedia (2002) Instrumental Variables}

\begin{tabular}{|l|l|}
\hline S\&P Index ${ }_{i t}$ & $\begin{array}{l}\text { An indicator equal to one if the firm was included in the S\&P 500 } \\
\text { during the fiscal-year; equal to zero otherwise. A firm is determined to } \\
\text { have been on the S\&P 500 during the year if there was at least one day } \\
\text { within the 12 months leading up and including the fiscal-year end date } \\
\text { that the firm was included in CRSP.DSP500LIST. }\end{array}$ \\
\hline $\begin{array}{l}\text { Listed } \text { on a Major Stock } \\
\text { Index }\end{array}$ & $\begin{array}{l}\text { An indicator equal to one if the firm is listed on Nasdaq, NYSE, or } \\
\text { AMEX, (EXCHG codes equal to 14, 11, or 12); equal to zero } \\
\text { otherwise }\end{array}$ \\
\hline $\begin{array}{l}\text { \# } \text { Contraction Months } \text { the Year } \\
\text { it }\end{array}$ & $\begin{array}{l}\text { The number of months in the calendar year the firm's fiscal-year-end } \\
\text { falls in that are classified as contraction months on the National } \\
\text { Bureau of Economic Research (NBER) U.S. Business Cycle } \\
\text { Expansions and Contractions document dated 9/20/10. Set equal to } \\
\text { zero if no contraction months on this document for the year. }\end{array}$ \\
\hline $\begin{array}{l}\text { Number of M\&A Announced } \\
\text { during the Year } \text { Yeal }_{i t}\end{array}$ & $\begin{array}{l}\text { The percent change in real Gross Domestic Product (GDP) not } \\
\text { seasonally adjusted from the St. Louis FRED for the calendar year the } \\
\text { firm's fiscal-year-end falls in. }\end{array}$ \\
$\begin{array}{l}\text { The aggregate number of deals announced in year } t \text { on SDC } \\
\text { Platinum's Mergers \& Acquisitions database including completed } \\
\text { deals for acquisitions of both U.S. and non-U.S. targets. To be } \\
\text { included the deal must have a non-missing date announced and deal } \\
\text { number and must not be a buyback or recapitalization. }\end{array}$ \\
\hline
\end{tabular}




\begin{tabular}{|l|l|}
\hline $\begin{array}{l}\text { Dollar Value of M\&A } \\
\text { Announced during the Year it }\end{array}$ & $\begin{array}{l}\text { The aggregate transaction value (in millions of dollars) of deals } \\
\text { announced in year } t \text { on SDC Platinum's Mergers \& Acquisitions } \\
\text { database including completed deals for acquisitions of both U.S. and } \\
\text { non-U.S. targets. To be included the deal must have a non-missing } \\
\text { date announced, deal number, and transaction value and must not be a } \\
\text { buyback or recapitalization. }\end{array}$ \\
\hline $\begin{array}{l}\text { Fraction of Industry Firms } \\
\text { that are Multi-Industy }\end{array}$ & $\begin{array}{l}\text { The percent of Compustat firms in the year with non-missing business } \\
\text { segment data that operate in multiple industries (Multiple industries } \\
\text { equal to one). }\end{array}$ \\
\hline $\begin{array}{l}\text { Fraction of Industry Sales } \\
\text { from Multi-Industry Firms }\end{array}$ & $\begin{array}{l}\text { The percent of sales for Compustat firms in the year with non-missing } \\
\text { business segment data that operate in multiple industries (Multiple } \\
\text { industries }\end{array}$ \\
\hline Incorporated Outside U.S. It $_{\text {it }}$ & $\begin{array}{l}\text { An indicator equal to zero if the country of incorporation (FIC) is } \\
\text { equal to USA; equal to one otherwise }\end{array}$ \\
\hline
\end{tabular}




\section{REFERENCES}

Amihud, Y. and B. Lev.1981. Risk Reduction as a Managerial Motive for Conglomerate Mergers. Bell Journal of Economics 12: 605-617.

Ammann, M., D. Hoechle, and M. Schmid. 2012. Is There Really No Conglomerate Discount? Journal of Business Finance \& Accounting 39 (1-2): 264-288.

Benoit, D. and K. Grind. “Activist Investors' Secret Ally: Big Mutual Funds: Large Investors quietly back campaigns to force change at U.S. companies," The Wall Street Journal, August 9, 2015, http://www.wsj.com/articles/activist-investors-secret-ally-big-mutual-funds-1439173910.

Berger, P. and E. Ofek. 1995. Diversification's Effect on Firm Value. Journal of Financial Economics 37: 39-65.

Bound, J., D. Jaeger, and R. Baker. 1995. Problems with Instrumental Variables Estimation when the Correlation between the Instruments and the Endogenous Explanatory Variable is Weak. Journal of the American Statistical Association 90 (430): 443-450.

Campa, J. M. and S. Kedia. 2002. Explaining the Diversification Discount. Journal of Finance 57 (4): 1731-1762.

Comment, R. and G. Jarrell. 1995. Corporate Focus and Stock Returns. Journal of Financial Economics 37 (1): 67-87.

Creal, D., L. Robinson, J. Rogers, and S. Zechman. 2013. The Multinational Advantage. Working paper no. 11-37, University of Chicago.

Devos, E., P. R. Kadapakkam, and S. Krishnamurthy. 2009. Review of Financial Studies 22 (3): 11791211.

Dimitrov, V. and S. Tice. 2006. Corporate Diversification and Credit Constraints: Real Effects across the Business Cycle. Review of Financial Studies 19 (4): 1465-1498.

Donohoe, M. 2015. The Economic Effects of Financial Derivatives on Corporate Tax Avoidance. Journal of Accounting and Economics 59 (1): 1-24.

Dyreng, S., M. Hanlon, and E. Maydew. 2008. Long-Run Corporate Tax Avoidance. The Accounting Review: 83 (1): 61-82.

Fama, E. and K. French. 2002. Testing Trade-Off and Pecking Order Predictions about Dividends and Debt. Review of Financial Studies 15 (1): 1-33.

Furrer, O. Corporate Level Strategy Theory and Applications. New York: Routledge, 2011.

Gallemore, J. and E. Labro. 2015. The Importance of the Internal Information Environment for Tax Avoidance. Journal of Accounting and Economics 60 (1): 149-167.

Gertner, R., D. Scharfstein, and J. Stein. 1994. Internal versus External Capital Markets. Quarterly Journal of Economics 109 (4): 1211-1230.

Goetz, M., L. Laeven, and R. Levine. 2013. The Valuation Effects of Geographical Diversification: Evidence from U.S. Banks. Review of Financial Studies 67 (7): 1787-1823. 
Gopalan, R. and K. Xie. 2011. Conglomerates and Industry Distress. Review of Financial Studies 24 (11): 3642-3687.

Gopinath, S. and K. Sikka. “Activist Investor Peltz Pushes DuPont to Split Itself,” Reuters, September 17, 2014, http://www.reuters.com/article/2014/09/17/us-e-i-du-pont-de-divestiture-idUSKBNOHC0C 220140917.

Graham, J., M. Lemmon, and J. Wolf. 2002. Does Corporate Diversification Destroy Value? The Journal of Finance 57 (2): 695-720.

Graham, J., and C. W. Smith Jr. 1999. Tax Incentives to Hedge. Journal of Finance 54 (6): 2241-2262.

Graham, J., and D. Rogers. 2002. Do Firms Hedge in Response to Tax Incentives? Journal of Finance 57 (2): 815-839.

Gupta, S. and K. Newberry. 1997. Determinants of the Variability in Corporate Effective Tax Rates: Evidence from longitudinal data. Journal of Accounting and Public Policy 16 (1): 1-34.

Hadlock, C. J. and J. R. Pierce. 2010. New Evidence on Measuring Financial Constraints: Moving Beyond the KZ Index. Review of Financial Studies 23 (5): 1909-1940.

Hanlon, M. and S. Heitzman. 2010. A Review of Tax Research. Journal of Accounting and Economics 50 (2-3): 127-178.

Hann, R., M. Ogneva, and O. Ozbas. 2013. Corporate Diversification and the Cost of Capital. Journal of Finance 68 (5): 1961-1999.

Henry, E., and R. Sansing. 2015. Data Truncation Bias and the Mismeasurement of Corporate Tax Avoidance. Working paper, University of Tennessee Knoxville and Dartmouth.

Hindle, T. 2009. "Diversification," The Economist, October 7, 2009, http://www.economist.com/node/ 14298922.

Hoechle, D., M. Schmid, I. Walter, and D. Yermack. 2012. How Much of the Diversification Discount Can be Explained by Poor Corporate Governance? Journal of Financial Economics 103 (1): 4160.

Hope, O., M. Ma, and W. Thomas. 2013. Tax Avoidance and Geographic Earnings Disclosure. Journal of Accounting and Economics 56: 170-189.

Humphery-Jenner, M. 2013. Diversification in Private Equity Funds: On Knowledge Sharing and Limited Attention. Journal of Financial and Quantitative Analysis 48 (5): 1545-1572.

Khorana, A., A. Shivdasani, C. Stendevad, and S. Sanzhar. 2011. Spin-offs: Tackling the Conglomerate Discount. Journal of Applied Corporate Finance 23 (4): 90-101.

Klein, P. and M. Saidenberg. 2010. Organizational Structure and the Diversification Discount: Evidence from Commercial Banking. Journal of Industrial Economics 58 (1): 127-155.

Lachapelle, T. "Buffett Critiques Breakup Ideas Even as Spinoffs Surge: Real M\&A," Bloomberg Press, March 1, 2015, http://www.bloomberg.com/news/articles/2015-03-01/buffett-critiques-breakupideas-even-as-spinoffs-surge-real-m-a. 
Laeven, L. and R. Levine. 2007. Is There a Diversification Discount in Financial Conglomerates? Journal of Financial Economics 85: 331-367.

Lang, L., and R. Stulz. 1994. Tobin's Q, Corporate Diversification and Firm Performance. Journal of Political Economy: 1248-1280.

Larcker, D. F. and T. O. Rusticus. 2010. On the Use of Instrumental Variables in Accounting Research. Journal of Accounting and Economics 49 (3): 186-205.

Leland, H. 1998. Agency Costs, Risk Management, and Capital Structure. Journal of Finance 53: 12131243.

Lewellen, W. 1971. A Pure Financial Rationale for the Conglomerate Merger. Journal of Finance 26 (2): 521-537.

Li, K. and N. R. Prabhala. "Self-Selection Models in Corporate Finance," in Handbook of Corporate Finance: Empirical Corporate Finance, ed. B. Espen Eckbo, vol. 1, 37-86. Amsterdam: Elsevier/North-Holland, 2007.

Lin, J., C. Pantzalis, and J. Park. 2007. Corporate Use of Derivatives and Excess Value of Diversification. Journal of Banking \& Finance 31: 889-913.

Lins, K. and H. Servaes. 1999. International Evidence on the Value of Corporate Diversification. Journal of Finance 54 (6): 2215-2239.

Lynch, P. and J. Rothchild. One up on Wall Street: How to Use What You Already Know to Make Money in the Market. New York: Simon \& Schuster/FIRESIDE, 2000.

Majd, S. and S. C. Myers. "Tax Asymmetries and Corporate Income Tax Reform," in Effects of Taxation on Capital Accumulation, ed. M. Feldstein. Chicago: University of Chicago Press, 1987.

Mann, T. "Price of Selling GE Capital? Tax Breaks," The Wall Street Journal, April 13, 2015, http://www.wsj.com/articles/price-of-ge-capital-sale-tax-breaks-1428970045.

Markides, C. “To Diversify or Not to Diversify," Harvard Business Review, November-December, 1997.

May, D. 1995. Do Managerial Motives Influence Firm Risk Reduction Strategies? Journal of Finance 50 (4): 1291-1308.

McGuire, S., T. Omer, and D. Wang. 2012. Tax Avoidance: Does Tax-Specific Industry Expertise Make a Difference. The Accounting Review 87 (3): 975-1003.

Montgomery, C. 1994. Corporate Diversification. Journal of Economic Perspectives 8 (3): 163-178.

Myers, S. C. 1984. The Capital Structure Puzzle. Journal of Finance 39 (3): 574-592.

Ohlemacher, S. "Senate Votes to Extend Tax Breaks through December," Huffington Post, December 16, 2014, http://www.huffingtonpost.com/2014/12/16/senate-tax-breaks_n_6337484.html.

Rajan, R., H. Servaes, and L. Zingales. 2000. The Cost of Diversity: The Diversification Discount and Inefficient Investment. Journal of Finance 55 (1): 35-80. 
Rego, S. 2003. Tax-Avoidance Activities of U.S. Multinational Corporations. Contemporary Accounting Research 20 (4): 805-833.

Robinson, J., S. Sikes, and C. Weaver. 2010. Performance Measurement of Corporate Tax Departments. The Accounting Review 85 (3): 1035-1064.

Scharfstein, D. and J. Stein. 2000. The Dark Side of Internal Capital Markets: Divisional Rent-seeking and Inefficient Investment. Journal of Finance 55: 2537-2564.

Smith, C. W. and R. M. Stulz. 1985. The Determinants of Firms' Hedging Policies. Journal of Financial and Quantitative Analysis 20 (4): 391-405.

Staiger, D., and J. Stock. 1997. Instrumental Variables Regression with Weak Instruments. Econometrica 65 (3): 557-586.

Stulz, R. 1996. Rethinking Risk Management. Journal of Applied Corporate Finance 9: 8-24.

Teece, D. 1980. Economies of Scope and the Scope of the Enterprise. Journal of Economic Behavior and Organization 1 (3): 223-247.

Villalonga, B. 2004a. Diversification Discount or Premium? New Evidence from the Business Information Tracking Series. Journal of Finance 59 (2): 479-506.

Villalonga, B. 2004b. Does Diversification Cause the 'Diversification Discount'? Financial Management 33 (2): 5-27.

Wieczner, J. “Activist Investors Love Spin-offs. Here's Why You Should, too,” Fortune, June 29, 2015, http://fortune.com/2015/06/29/fortune500-spin-off-stocks/.

Wooldridge, J. "Instrumental Variables Estimation of Single-Equation Linear Models," in Econometric Analysis of Cross Section and Panel Data, Cambridge, MA; London, England: The MIT Press, 2002.

Zheng, S. 2015. Firm Diversification, Corporate Governance and Tax Avoidance. Working paper, University of Cincinnati.

Zimmerman, J. 1983. Taxes and Firm Size. Journal of Accounting and Economics 5: 119-149. 